\title{
Child-Pedestrian Traffic Safety at Crosswalks-Literature Review
}

\author{
Aleksandra Deluka-Tibljaš ${ }^{1, * \mathbb{C}}$, Sanja Šurdonja ${ }^{1}{ }^{(\mathbb{D}}$, Irena Ištoka Otković ${ }^{2}{ }^{\mathbb{D}}$ and Tiziana Campisi ${ }^{3}{ }^{\mathbb{D}}$ \\ 1 Faculty of Civil Engineering, University of Rijeka, 51000 Rijeka, Croatia; sanja.surdonja@uniri.hr \\ 2 Faculty of Civil Engineering and Architecture Osijek, Josip Juraj Strossmayer University of Osijek, \\ 31000 Osijek, Croatia; iirena@gfos.hr \\ 3 Faculty of Engineering and Architecture, Kore University of Enna, 94100 Enna, Italy; \\ tiziana.campisi@unikore.it \\ * Correspondence: aleksandra.deluka@uniri.hr; Tel.: +385-997-370-427
}

check for updates

Citation: Deluka-Tibljaš, A.; Šurdonja, S.; Ištoka Otković, I.; Campisi, T. Child-Pedestrian Traffic Safety at Crosswalks-Literature Review. Sustainability 2022, 14, 1142 https://doi.org/10.3390/ su14031142

Academic Editor: Elżbieta Macioszek

Received: 20 December 2021

Accepted: 14 January 2022

Published: 20 January 2022

Publisher's Note: MDPI stays neutral with regard to jurisdictional claims in published maps and institutional affiliations.

Copyright: (C) 2022 by the authors. Licensee MDPI, Basel, Switzerland. This article is an open access article distributed under the terms and conditions of the Creative Commons Attribution (CC BY) license (https:// creativecommons.org/licenses/by/ $4.0 /)$.

\begin{abstract}
Child pedestrians make up 30\% of the total number of children injured in road traffic in the EU. They are a particularly vulnerable subgroup because they exhibit specific traffic behavior related to cognitive and physical development, sociodemographic characteristics, and environmental conditions. This paper provides an overview of research of parameters that affect the safety of children in the conflict zones of the intersection-crosswalks. The overview was undertaken targeting available research mostly conducted in the last 10 years all over the world, related to the identification of parameters that affect the safety of child-pedestrians, and models developed for the prediction of pedestrian and child-pedestrian behavior. Research conducted on various urban networks provides insight into locally and more widely applicable impact parameters connected to child characteristics and infrastructural and traffic elements, but also distractors (e.g., electronic devices) as new phenomena influencing children's road safety. A review of pedestrian behavior-prediction models suggests that models are being developed for the general population, and models for children's behavior, with specific parameters, are missing. For further research, more detailed analysis of the impact of distractors and of COVID-19 pandemic non-mobility, as well as an analysis of possible infrastructural solutions to increase children's road traffic safety, is suggested.
\end{abstract}

Keywords: child-pedestrian safety; intersection; crosswalks; influencing parameters; pedestrian behavior models

\section{Introduction}

Traffic safety data at world level [1] have established some factors that presently have influence on road safety, among which there are changes in demographic composition, where higher risks detected for people aged 75 and more, and distractions connected to mobile phone use are growing issues all over the world. In the same report, it was established on the basis of 34 countries that the number of child fatalities in road crashes fell by $29 \%$ on average across countries between 2010 and 2018, more than four times as fast as for the overall population. However, the road traffic safety of children in low- and middle-income countries remains a major concern. Worldwide, road crashes continue to be the number one killer of children and young people aged 5-29 years, according to the World Health Organization. In EU member countries, the number of road traffic fatalities is on average decreasing. According to official data on EU road safety [2], child-pedestrians aged under 15 years represent $4.4 \%$ of all pedestrian fatalities. Even the data looks optimistic, as was stated in the Dekra Road Safety Report [3] the goal is "vision zero" and to achieve this, it is especially important to tailor the respective measures as exactly as possible to local accident statistics.

Local statistics for Croatia show similar trends to the ones established in Europeoverall traffic safety data got better during the last decade, but were not as good as planned in the National plan [4] for road traffic safety improvement. The goal was to decrease the 
number of road traffic victims by $50 \%$ by 2020 , but it was not fully accomplished. The trend considering children's traffic safety was very favorable up to 2018; from 38 child victims in traffic accidents in 2011, the number decreased to 8 (or 9) child traffic victims during the period 2012-2016, but then in 2017. and especially 2019, the number increased markedly. In 2019 , according to national statistics [5] there were 18 traffic victims aged up to 17 years, of which 6 were pedestrians. Child pedestrians represented $10 \%$ of all killed pedestrians in 2019 in Croatia.

Considering the data of the Italian National Institute of Statistics [6], in Italy, the number of victims between $0-14$ years has not decreased in the last 10 years. The ages with the highest number of deaths are those between $0-5$ years and 11-14 years, and the latter is the category with the highest risk of road accidents. A study carried out in 16 European countries, including Italy, showed that Italian children practice independent mobility on average at a later age than in the other EU countries, in contrast to Finland, where children are classified as the most independent [7].

Various studies show different hazard perceptions of current traffic situations in different age groups of pedestrians [8], applying virtual reality technology to identify risky pedestrian behaviors among Chinese children. The impact of cognitive and perceptual development on the pedestrian behavior of children, and the roles of distraction, temperament and personality, and social influences from parents and peers, were analyzed and discussed. According to research, parents have high expectations of preschool and early school children, and less than $20 \%$ of surveyed parents know that the cognitive abilities of children in this developmental stage are such that they cannot fully process complex traffic situations and assess risk $[9,10]$.

Sometimes it is difficult to identify all the elements of a potentially unsafe crossing of a conflict zone by observing only the behavior of children in videos in real traffic conditions. A study conducted in China [11] using eye-tracking equipment included 10 children who passed through an unsignalized intersection, an unsignalized T-intersection and a signalized intersection. When crossing the three types of intersections, the children allocated more fixation points and a larger proportion of fixation time in the small area in front of their bodies and the most common unsafe behavior was crossing without observing the traffic environment. The frequency of left and right observations of the traffic environment was low, reaching the lowest level at the unsignalized T-intersection. Although the study was conducted on a small sample, the results indicate that additional attention needs to be paid to the traffic safety of children in the crosswalk zones.

Child road traffic safety has many aspects, and it is therefore subject to different types of research among scientists in different disciplines. It considers different types of topics and analyses:

- $\quad$ analyses of traffic accidents involving children and young people in different roles (as pedestrians, cyclists or car passengers);

- $\quad$ analyses of traffic-related injuries;

- analyses of children's and young people's traffic behavior (depending on their age, gender and other sociodemographic characteristics, and use of mobile phones and other distractors);

- analyses of the role of infrastructural solutions in children road traffic safety;

- analyses of the efficiency of traffic education in assuring safe traffic behavior in the young population and other demographics.

All these elements are equally important when children's traffic safety is considered. The goal of this paper is to give an overview of the research on the traffic safety of child pedestrians in urban road networks, with emphasis on the conflict area of pedestrian crosswalks. The idea is to analyze available published research to identify parameters that are most influential for child pedestrians in the riskiest traffic situation-when they are approaching and crossing the street. In the second part of the paper, a literature review and extensive analysis of research published mostly in the last ten years is presented. Parameters influencing child traffic safety connected to children's sociodemographic characteristics, 
infrastructural and traffic solutions and distractors (e.g., mobile phone use) are identified. In the third part, available models for pedestrian and child-pedestrian behavior in the area of pedestrian crosswalks are presented and compared. As the authors previously undertook an extensive study and developed original models for children's speed at signalized crosswalks, results are also compared and further elaborated in the third part of this paper. In the Discussion and Conclusion part of the paper, conclusions are given based on the comprehensive analysis undertaken in the paper, as well as the guidelines for further research regarding child traffic safety in urban areas.

\section{Parameters Influencing Children's Traffic Safety at Crosswalks-Literature Review}

Analyses of existing research regarding child-pedestrians in the area of signalized pedestrian crosswalks conducted by the authors in previous papers [12-15] detected the main group of parameters that affect children's traffic behavior. These are: sociodemographic parameters and children's ways of moving (e.g., age, gender, supervising, moving in a group), urban, infrastructural, and traffic parameters (e.g., crosswalk width and length, signal timing), and risky behavior involving distractors (e.g., use of mobile phone). The parameters were investigated in the extensive study conducted simultaneously in two cities in Croatia (Osijek and Rijeka) and one in Italy (Enna). Around 300 children's crossings were recorded and analyzed in each city to establish influencing parameters of local and wider importance [12]. The same data series was used for developing regression and neural network-based models for children's pedestrian speed at signalized intersections [13].

In the following parts of this paper, those aged 5-15 years are considered children, and when young people are mentioned, it implies those aged up to 18 years.

\subsection{Sociodemographic Parameters Influencing Child-Pedestrian Traffic Safety}

A review of available literature and research, as well as the authors' research itself, [14] highlighted the significant impact of sociodemographic factors (age, gender, supervising and group movement) on children crossing behavior.

Adults generally have fully developed cognitive skills for safe risk-taking, and do not necessarily avoid participating in all risk behaviors, but are better at taking calculated risks. A study conducted by Barton \& Schwebel [16] compared the behavior of children and adults and concluded that significantly different behavior of children was observed insofar as predicting safe traffic gaps since anticipation is the most cognitively complex task in traffic behavior.

Similar results were given in the studies [17-20] where it was shown that children are less skilled in crossing the road compared to adults, as expressed in their poorer ability to evaluate the dangers in the road environment, as they suffer from poor visual search strategies and are less capable at identifying hazardous situations. Some research shows that the younger children are, the greater their relative inability to correctly perceive or understand the potential danger $[20,21]$. Therefore, children need to be analyzed separately as a specific group of vulnerable road users.

\subsubsection{The Influence of Child-Pedestrian Age on Their Traffic Safety}

The results of research [22] on the inhabitants of southern Poland showed that children, especially smaller children ( $0-6$ years) are most often unaware of the dangers of traffic, and for them it is difficult to assess whether the vehicle is moving at all, if it is a matter of lower speeds. If they focus on several things at once, they usually stop paying attention to traffic conditions.

Pedestrians' hazard perception (HP) abilities vary with age and experience, and the youngsters' HP skills may be highly influenced by cueing [23]. The reason certainly lies in the fact that children in middle childhood, (5-6 years old), are most often not cognitively able to simultaneously solve several tasks necessary for safe pedestrian activity [24].

Older children (7-14 years old), on the other hand, may be more successful in focusing on simultaneous information from multiple sources to handle pedestrian crossings and realistically estimate the risk. From the age of 11 , they have a relatively good spatial 
orientation, the perception of sounds is fully developed, and the field of view is also increasing. Therefore, although they react more slowly than adults, this age group (up to 14 ) is considered safer in traffic than the previously analyzed age group (5-6 years old). On the other hand, older children (15-18 years old) as well as adults are more competent to consider the speed, distance, and acceleration of multiple vehicles from multiple directions, as well as the speed at which they can physically cross a pedestrian crosswalk [16], but often ignore traffic rules and dangers, although they can assess traffic situations more realistically than the previous groups [22].

The influence of children's ages on the ability to recognize safe and dangerous road crossing points related to age differences in attention capacity, was also examined by Tabibi and Pfeffer [25] and the results showed that the ability increases from the age of 10 or 11 years, but no significant difference was found between older children and adults. However, the difference between adults and 10-11-year-olds in terms of the time required to identify safe and dangerous crossing points was evident, with 10-11-year-olds taking much longer than adults in all conditions.

The older children (11-13 years) shared the most resemblance in the crossing measures, and performed better than the younger children (aged 7-10), so it can be concluded that road-crossing performance improves with age [26], which is also in agreement with the results of authors Meir et al. [20]. However, it is important to notice that in other measures (for example, response to a crossing opportunity) children aged 11-13 still behave like younger children (7-10 years): slower. It can be assumed that children aged 11-13 are more competent to understand the risks involved in road crossing than younger children, and show the most resemblance to adults in their crossing behavior, while children aged 9-10 show more resemblance to the youngest children's group (aged 7-8) in several indicators [26].

Results from research by Oxley et al. showed that younger children (6-7 years) were 12 times more likely than older children (8-10 years) to make critically incorrect (or unsafe) crossing decisions [27], similarly to the results of Wang et al. [28], which also confirmed young children perform poorly in crossing and walking behaviors, while older pupils perform better than younger children.

The influence of children's age on movement speed on crosswalks in two cities in Croatia and one city in Italy confirmed that the crossing speed of children increases with age (up to 12 years of age) [12].

\subsubsection{The Influence of Child-Pedestrian Gender on Their Traffic Safety}

Differences in children's behavior regarding gender are expressed to a much lesser extent in relation to the age difference. In their study, the authors Tabibi and Pfeffer [18] come to similar conclusions related to the lack of gender differences in the ability to identify a road-crossing site as safe or dangerous, and which agree with the conclusions of another research [12,27,29-31].

Considering the gender and the age of the children, authors Wang et al. [32] concluded that boys and girls of different ages display distinct characteristics on and near roadways. Across development, boys played and ran/hopped more often, while girls preferred to walk with partners. Moreover, between children in grades 3-4, there were substantial gender differences between boys and girls, with boys behaving in riskier ways than girls at that age. With increasing age through grade 6 , girls behaved more safely on roads, but boys did not show increasing safety.

Similar results were obtained by the authors Wang et al. [33], according to which male adolescents reported more unsafe road behaviors than female adolescents.

Barton \& Schwebel [16] confirmed that among the observed children, girls waited longer than boys and attended to traffic more than boys, who missed fewer opportunities to cross than girls and engaged in more anticipations than girls.

Simeunovic et al. [34] measured the speed of children in different walking regimes (Slow walk, Normal walk, Fast walk, Run and Rush) in a controlled environment, and 
according to their results, the influence of gender exists to a lesser extent at younger ages and becomes moderately significant at older ages; for all faster regimes of walking or running, there are significant differences in average speeds in favor of male subjects.

\subsubsection{The Influence of the Way of Moving on Child-Pedestrian Traffic Safety}

Parental supervision is among the most effective behavioral techniques for reducing pediatric injury risk [35], and likely influences children's pedestrian safety.

According to Schwebel \& Barton [36], supervision may influence pedestrian behavior as a moderator of the link between inhibitory control and injury risk. Furthermore, recent laboratory study results suggested that one way to reduce children's tendency toward overestimation of ability is to intensify parental supervision while children make judgments about ability [37].

In the study $[16,38]$, results show that children had more missed opportunities when fully supervised than when visually supervised, and had significantly more tight fits when unsupervised, visually supervised, and fully supervised, in comparison with partial supervision. Furthermore, children behaved somewhat more cautiously when supervised but crossing without a parent.

Children's crossing behavior is significantly influenced by the presence of adults, as indicated by the results of authors Schwebel et al. [30]. In the presence of either a police officer or adult crossing guard all the time, children followed adult advice provided during the crossing in $70 \%$ of the times/crossings, suggesting children were making their own decisions about when to cross $30 \%$ of the time.

One of the important parameters influencing children's crossing behavior is moving in a group. Those children who crossed the road on their own showed more risk-taking crossing behavior [31] and they walked faster than children who crossed in a group [12].

Table 1 shows in chronological order different studies that have correlated sociodemographic factors (gender, age, supervising and group movement) with children's crossing behavior.

Table 1. Sociodemographic factors influencing children's traffic safety-overview of available papers.

\begin{tabular}{|c|c|c|c|c|}
\hline Source & Objective & Method & Target Group/Sample & $\begin{array}{l}\text { Parameters } \\
\text { Analyzed }\end{array}$ \\
\hline $\begin{array}{c}\text { Ampofo-Boateng \& Thomson, } \\
1991 \text { [29] }\end{array}$ & $\begin{array}{l}\text { children's perception of safety } \\
\text { and danger }\end{array}$ & $\begin{array}{l}\text { laboratory table-top } \\
\text { simulation }\end{array}$ & $\begin{array}{l}\text { children (5-11 years) } / 64,48,48 \\
\text { and } 24 \text { children }\end{array}$ & age, gender \\
\hline Whitebread \& Neilson, 2000 [24] & $\begin{array}{l}\text { development of pedestrian } \\
\text { skills }\end{array}$ & $\begin{array}{l}\text { laboratory tasks and video } \\
\text { presentations }\end{array}$ & $\begin{array}{l}\text { children ( } 4-5,7-11 \text { years)/ } \\
60 \text { children and } 10 \text { adults }\end{array}$ & age \\
\hline Hill et al., 2000 [17] & children's concepts of danger & two experiments & $\begin{array}{l}\text { children (4-10 years)/ } 120 \text { children } \\
\text { and } 30 \text { adults }\end{array}$ & age, gender \\
\hline Schwebel \& Bounds, 2003 [37] & $\begin{array}{l}\text { children's estimation of } \\
\text { physical ability }\end{array}$ & laboratory experiment & $\begin{array}{l}\text { children ( } 6 \text { and } 8 \text { years)/ } \\
64 \text { children }\end{array}$ & supervision \\
\hline Tabibi \& Pfeffer, 2003 [18] & $\begin{array}{l}\text { identification of safe and } \\
\text { dangerous road-crossing sites }\end{array}$ & computer presentations & children/95 children & age, gender \\
\hline Tabibi \& Pfeffer 2007 [25] & $\begin{array}{l}\text { children's pedestrian } \\
\text { behaviors }\end{array}$ & laboratory testing & $\begin{array}{c}\text { children (6-11 years) / } 88 \text { children } \\
\text { and } 29 \text { adults }\end{array}$ & age \\
\hline Barton and Schwabel, 2007. [16] & $\begin{array}{l}\text { children's pedestrian } \\
\text { behavior }\end{array}$ & $\begin{array}{l}\text { pretend road method, real } \\
\text { road crossing }\end{array}$ & children/ 85 children and 26 adults & $\begin{array}{l}\text { age, gender, parental } \\
\text { supervision }\end{array}$ \\
\hline Oxley et al., 2007 [27] & road-crossing judgements & $\begin{array}{l}\text { simulated road-crossing task, } \\
\text { performance assessments and } \\
\text { a survey }\end{array}$ & children (6-10 years)/ 71 children & age, gender \\
\hline Rosenbloom et al., 2008 [38] & children's crossing behavior & unobtrusive observations & children (7-11 years)/ 269 children & supervision \\
\hline Tapiro et al., 2014 [19] & $\begin{array}{l}\text { children's pedestrian } \\
\text { behaviors }\end{array}$ & $\begin{array}{l}\text { laboratory testing using the } \\
\text { eye tracker }\end{array}$ & $\begin{array}{l}\text { children ( } 7-13 \text { years) } / 21 \text { adults } \\
\text { and } 33 \text { children }\end{array}$ & age \\
\hline Meir et al., 2013 [21] & $\begin{array}{l}\text { child pedestrians' hazard } \\
\text { perception }\end{array}$ & $\begin{array}{l}\text { virtual environment } \\
\text { simulation laboratory }\end{array}$ & $\begin{array}{l}\text { children ( } 7-13 \text { years) } / 22 \text { adults } \\
\text { and } 25 \text { children }\end{array}$ & age \\
\hline Meir et al., 2015 [20] & $\begin{array}{l}\text { child pedestrians' hazard } \\
\text { perception }\end{array}$ & $\begin{array}{l}\text { virtual environment } \\
\text { simulation laboratory }\end{array}$ & $\begin{array}{l}\text { children }(7-13 \text { years }) / 20 \text { adults } \\
\text { and } 27 \text { children }\end{array}$ & age \\
\hline
\end{tabular}


Table 1. Cont.

\begin{tabular}{|c|c|c|c|c|}
\hline Source & Objective & Method & Target Group/Sample & $\begin{array}{l}\text { Parameters } \\
\text { Analyzed }\end{array}$ \\
\hline Fu \& Zou, 2016 [31] & $\begin{array}{l}\text { children's crossing } \\
\text { behavior }\end{array}$ & video recording at & $\begin{array}{l}\text { children all ages/1154 children } \\
\text { and } 1096 \text { children }\end{array}$ & gender \\
\hline Schwebel et al., 2018 [30] & $\begin{array}{l}\text { child pedestrian } \\
\text { street-crossing behaviors }\end{array}$ & videotaping 3 crosswalks & $\begin{array}{l}\text { children ( } 1-6 \text { grades }) / \\
216 \text { children }\end{array}$ & age, gender, supervision \\
\hline Tapiro et al., 2018 [26] & pedestrian crossing behavior & laboratory testing & $\begin{array}{l}\text { children ( } 7-13 \text { years)/ } \\
38 \text { children and } 14 \text { adults }\end{array}$ & age \\
\hline Wang et al., 2018a [28] & $\begin{array}{l}\text { children's pedestrian } \\
\text { behavior }\end{array}$ & $\begin{array}{l}\text { videotaping crosswalk and } \\
\text { sidewalk }\end{array}$ & $\begin{array}{l}\text { children ( } 6-14 \text { years }) / \\
469 \text { children }\end{array}$ & age, gender \\
\hline Wang et al., 2018b [32] & $\begin{array}{l}\text { children's pedestrian } \\
\text { behavior }\end{array}$ & $\begin{array}{l}\text { videotaping crosswalk and } \\
\text { sidewalk }\end{array}$ & $\begin{array}{l}\text { children ( } 6-14 \text { years }) / \\
491 \text { children }\end{array}$ & age, gender \\
\hline Wang et al., 2019 [33] & behavior of adolescents & $\begin{array}{l}\text { road user behavior } \\
\text { questionnaire }\end{array}$ & $\begin{array}{l}\text { children all ages/ } \\
4794 \text { adolescents }\end{array}$ & age, gender \\
\hline Meir et al., 2020. [23] & $\begin{array}{l}\text { children-pedestrians' hazard } \\
\text { perception }\end{array}$ & $\begin{array}{l}\text { two experimental } \\
\text { measurements }\end{array}$ & $\begin{array}{c}\text { children ( } 7-13 \text { years) and } \\
\text { adults } / \text { in } 1 \text { st. } \\
20 \text { adults }+30 \text { children; } \\
\text { in } 2 \text { nd } 21 \text { adults }+25 \text { children }\end{array}$ & age \\
\hline Simeunović et al., 2021 [34] & speed of school age children & experimental measurements & $\begin{array}{l}\text { pedestrians ( } 7-20 \text { years) / } \\
643 \text { children and adolescents }\end{array}$ & $\begin{array}{l}\text { age, and } \\
\text { gender }\end{array}$ \\
\hline Cieśla, 2021 [22] & infrastructure solutions & $\begin{array}{l}\text { statistical data and survey } \\
\text { method }\end{array}$ & $\begin{array}{l}\text { children ( } 0-18 \text { years)/ } \\
217 \text { survey participants }\end{array}$ & age \\
\hline Deluka-Tibljaš et al., 2021 [14] & Children's traffic behavior & videotaping 14 crosswalks & $\begin{array}{l}\text { children up to } 15 \text { years / } \\
600 \text { crossings }\end{array}$ & $\begin{array}{l}\text { age, gender, parental } \\
\text { supervision, group } \\
\text { movement }\end{array}$ \\
\hline
\end{tabular}

\subsection{Infrastructural and Traffic Parameters Influencing Children's Pedestrian Safety at Crosswalks}

The type of urban environment a child pedestrian walks within impacts their safety in different ways. Different studies show that children are at greatest risk in urban, populated areas [39] even though the perception of risk is different. Studies that deal with the perception of risk show that, for example, residential streets are often perceived as riskier in terms of traffic safety, but as children act with more caution they get injured less [40].

When analyzing the locations within the city road network where children mostly get injured, these are areas and corridors where children regularly move: in residential and mixed-use zones [39-42], at intersections and/or at pedestrian crosswalks [22,42-45] and near schools and parks [46].

Pedestrian crosswalks have been detected as particularly vulnerable places for children to be injured in a very extensive study on children traffic safety in Poland. Of the total number of children killed in traffic accidents during 2019 in Poland, $12.2 \%$ died at pedestrian crosswalks, and the same study shows that when assessing traffic hazards for children and young people, respondents emphasize pedestrian crosswalks [22].

A study conducted in China shows that a higher share of children's risky behavior is recorded at traffic-lighted crosswalks than at non-traffic-lighted pedestrian crosswalks [45].

The behavior of child pedestrians, and consequently their traffic safety in pedestrian crossing zones, is largely related to the infrastructural parameters of the pedestrian crosswalk itself-length and width, design (traffic signals, accessories), method of control at the crosswalk and the time crossing child-pedestrians have at their disposal. Several studies have shown that in this sense it is important to respect the specifics of child-pedestrians on the corridors on which they move independently, and these are certainly the corridors to schools, playgrounds and similar. One of the pronounced specifics of children's movement is the speed at which they cross pedestrian crosswalks, which can be largely related to the conditions at the pedestrian crosswalk - the length of green time, the length of clearance time [14] and the length of pedestrian crosswalks [14,47].

Studies conducted in real conditions in different parts of the world (China, India, EU) indicate the influence of the length of the pedestrian crosswalk on the speed of pedestrians in all categories, including children $[14,48,49]$. In addition to the length of the pedestrian crosswalk, the study [49] observed the impact of pedestrian crosswalk width, road cate- 
gory, motor speed and the existence of a pedestrian island on the speed of all pedestrian categories, including youth. An analysis in a study of children's behavior on four typical mid-block crosswalks with no signal control conducted in China [50] suggests a significant difference in the speed of child-pedestrians on the second half of the road (in some cases they also run) when children cross a street with more than two lanes, which can potentially be risky. Very similar was the conclusion in the authors' study conducted in Croatia, where, for more than two lanes on crosswalks regularly used by children, pedestrian islands are suggested [14].

A study conducted in Sharjah, UAE, on the basis of 708 pedestrians including $8.6 \%$ children under the age of 15 [51] showed the effects of the number of lanes and green light duration on pedestrian walking speed, but also that adults walking with children in general walked slower than when walking alone or in a group with other adults. In general, more lanes and shorter green time influenced higher walking speed in the analyzed sample.

A study conducted near 6 schools in Idaho, USA [47] also determined the impact of vehicle approach speed on the speed of child pedestrians at non-traffic-light pedestrian crosswalks.

Analyses of child-pedestrian speed conducted by the authors in Croatia at signalized crosswalks with different infrastructural and traffic conditions [14] established both crosswalk length and the characteristics of traffic light cycles and the pedestrian green light, to influence children's speed. Children walked significantly faster on longer crosswalks as well as when pedestrian green lights were shorter. The same research also proved that it is necessary to implement different traffic parameters when children are expected regularly at crosswalks; for example, expected walking speed is slower than usually used.

In addition to the above basic parameters of infrastructure, recent research also emphasizes the effect of the road environment on the behavior of child pedestrians, where visual clutter in the road vicinity is created by excess numbers of vehicles and advertisement signs. The laboratory-based research study was conducted in Israel by Tapiro et al. [52] with the aim of establishing the effect of environmental distractions on children (aged 9-13) and adults. Children 9-10 and 11-13 years old had a wider view across the scene when the environment was highly loaded - an effect not seen with adults. The final conclusion was that according to the results, it is reasonable to assume that busier road environments can be more hazardous to adult and child pedestrians [52].

In the study conducted in Israel [23], child-pedestrians' hazard-perception skills were examined via a paired comparison task and via a crossing decision task in dynamic complex road traffic settings. The laboratory study was conducted in parallel on adults and children aged 7-13 years, and the results were compared. Perceptions of some infrastructural elements, such as type of intersection, showed no significant difference in crossing reaction at T-intersections, but adults were faster in reaction, and therefore more confident at crossing streets at roundabouts than children.

Table 2 provides an overview of the papers in which the impact of transport infrastructure on the safety and behavior of children in pedestrian crossing zones is analyzed, also listing research objectives, methods, and target groups.

Table 2. Urban, traffic and infrastructural parameters influencing child traffic safety-overview of available papers.

\begin{tabular}{ccccc}
\hline Source & Objective & Method & $\begin{array}{c}\text { Target Group/ } \\
\text { Country }\end{array}$ & $\begin{array}{c}\text { Parameters } \\
\text { Analyzed }\end{array}$ \\
\hline $\begin{array}{c}\text { Chandra and Bharti, } \\
\text { 2013 [53] }\end{array}$ & $\begin{array}{c}\text { crossing speed } \\
\text { analyses }\end{array}$ & field observation & $\begin{array}{c}\text { general } \\
\text { population/India }\end{array}$ & $\begin{array}{c}\text { road width, number of } \\
\text { lanes }\end{array}$ \\
\hline Li P et al., 2013 [50] & crossing speed analyses & $\begin{array}{c}\text { field observations by } \\
\text { video recording }\end{array}$ & $\begin{array}{c}\text { adults and children, } \\
\text { China }\end{array}$ & traffic lanes \\
\hline
\end{tabular}


Table 2. Cont.

\begin{tabular}{|c|c|c|c|c|}
\hline Source & Objective & Method & $\begin{array}{l}\text { Target Group/ } \\
\text { Country }\end{array}$ & $\begin{array}{l}\text { Parameters } \\
\text { Analyzed }\end{array}$ \\
\hline Li et al., 2013 [50] & $\begin{array}{l}\text { children's crossing } \\
\text { speed analyses }\end{array}$ & $\begin{array}{l}\text { field observations by } \\
\text { video recording }\end{array}$ & $\begin{array}{l}\text { children (aged 5-10), } \\
\text { adults/China }\end{array}$ & $\begin{array}{l}\text { road width, number of } \\
\text { lines, traffic volume }\end{array}$ \\
\hline Muley et al., 2018 [54] & $\begin{array}{l}\text { crossing speed } \\
\text { analyses }\end{array}$ & field observation & $\begin{array}{c}\text { general population, } \\
\text { Qatar }\end{array}$ & crosswalk length \\
\hline Fridman et al., 2019 [43] & $\begin{array}{l}\text { child-pedestrian } \\
\text { injuries }\end{array}$ & $\begin{array}{c}\text { modified } \\
\text { quasi-induced } \\
\text { exposure approach }\end{array}$ & $\begin{array}{l}\text { child pedestrians (aged } \\
\text { up to 18)/Canada }\end{array}$ & $\begin{array}{l}\text { control device presence, } \\
\text { road type, road } \\
\text { alignment, position at } \\
\text { road network }\end{array}$ \\
\hline Bansal et al., 2019 [49] & $\begin{array}{l}\text { pedestrian speed } \\
\text { model }\end{array}$ & $\begin{array}{l}\text { field observations by } \\
\text { video recording }\end{array}$ & $\begin{array}{l}\text { general population, } \\
\text { India }\end{array}$ & $\begin{array}{c}\text { traffic volumes, } \\
\text { number of lanes, nature } \\
\text { of land-use }\end{array}$ \\
\hline $\begin{array}{c}\text { Meir, A., \& Oron-Gilad, } \\
2020 \text { [23] }\end{array}$ & $\begin{array}{l}\text { estimation of road } \\
\text { crossing situations }\end{array}$ & $\begin{array}{c}\text { laboratory testing } \\
\text { (pair-comparison task, } \\
\text { virtual reality) }\end{array}$ & $\begin{array}{l}\text { adults and children } \\
\text { (7-13), Israel }\end{array}$ & $\begin{array}{l}\text { traffic regime, parked } \\
\text { cars, type of } \\
\text { intersection }\end{array}$ \\
\hline Tapiro et al., 2020 [52] & crossing behavior & virtual reality & children (9-13), Israel & $\begin{array}{c}\text { road environment } \\
\text { complexity }\end{array}$ \\
\hline $\begin{array}{l}\text { Deluka-Tibljaš et al., } \\
2021 \text { [14] }\end{array}$ & $\begin{array}{l}\text { children's crossing } \\
\text { speed }\end{array}$ & $\begin{array}{l}\text { field observations by } \\
\text { video recording }\end{array}$ & $\begin{array}{l}\text { children } \\
\text { (5-15), Croatia }\end{array}$ & $\begin{array}{l}\text { crosswalk length, } \\
\text { crosswalk width, } \\
\text { pedestrian green time } \\
\text { duration, traffic signal } \\
\text { cycle length }\end{array}$ \\
\hline Maria Cielsa, 2021 [22] & $\begin{array}{c}\text { urban transport } \\
\text { infrastructure solutions }\end{array}$ & surveys & $\begin{array}{c}\text { children } \\
\text { (aged } 0-18) / \text { Poland }\end{array}$ & $\begin{array}{l}\text { safety of infrastructural } \\
\text { elements—crosswalks, } \\
\text { road equipment }\end{array}$ \\
\hline
\end{tabular}

\subsection{Distractors}

Pedestrians are subject to an increasing number of potential distracting stimuli from the road environment [26] and the use of devices.

This is a problem that has not yet been adequately addressed, and the results should be considered by transport professionals and road safety educators so that better road safety programs can be created to educate pedestrians, starting with children.

The main distractions for pedestrians that inhibit situational awareness when crossing the road are the use of smartphones (talking on a mobile phone, writing text messages, listening to music with an iPod and consulting the internet) but also looking at something other than the direction of travel, talking to friends, looking at the clock, looking for something in a bag or rucksack, eating, reading a newspaper or book or being overthought.

People are often distracted by their smartphones not only when driving a car, but also when crossing the road. While in the first case there is a clear rule that sanctions the driver with a fine and a suspended license, in the second case the obligation to pay attention is not so explicit. In many European contexts there is no explicit provision for this as there is for driving a motor vehicle.

Recent literature mentions a new neologism: 'smombies'. These are pedestrians with eyes glued to the screens of their smartphones wandering the city, often in a hurry, unaware of potential dangers, even fatal ones.

Several studies point out that 'smombies' are one of the most endangered categories of road users. Indeed, with the increasing dependence on smartphones for everyday activities, a large number of pedestrians nowadays are constantly fixated on their smartphone screens, and are therefore susceptible to walking off the pavement or colliding with other pedestrians [15]. Reduced attention and situational awareness can make smartphone-occupied users unaware of potential risks when using their smartphones while walking or driv- 
ing [14]. According to [55], 'smombies' are generally between 18 and 24 years old and do not shy away from talking on the phone while crossing the street. A study conducted by Ford [55] showed that among European countries, Romania has the highest number of people $(83 \%)$ who admit using a smartphone while crossing the road. This is followed by Italy $(67 \%)$ and Spain (65\%). Research has shown that engaging in an aurally distracting activity can cause pedestrians to miss salient objects in their environment. Specifically, the research found that all child pedestrians, even those who were proficient at talking on a mobile phone, took more risks when talking on a mobile phone with one of the search assistants than when they were not distracted by their phones. The distracted children in the Alabama search took longer to start crossing the road and were more likely to be hit by a vehicle or have a close call when they were on their phones [56].

Several technologies have been developed to reduce distraction from smartphone use, such as RFID technology [57] or the creation of specific applications for smartphones and tablets [58].

One study also considers a new solution that can overcome these limitations, and it analyzed the latest ICT trends focused on features to use "smombie" prevention, especially video recognition and digital signage [59].

In order to improve the safety of smartphone pedestrian users, attempts have been made to install traffic lights on pavements or to warn users of approaching vehicles through mobile applications. However, the effectiveness of these "smombie" warning systems has not yet been studied in depth [60].

Table 3 below shows in chronological order a series of scientific studies that have correlated the use of mobile phones as a potential distractor during the crossing phase with sociodemographic data (gender, age), but also location and conflicts.

Table 3. Use of mobile phones as distractor among pedestrians-overview of available papers.

\begin{tabular}{|c|c|c|c|c|}
\hline Source & Objective & Method & Target Group/Sample & $\begin{array}{l}\text { Parameters } \\
\text { Analyzed }\end{array}$ \\
\hline Dunbar et al., 2001 [61] & $\begin{array}{l}\text { concentration (while } \\
\text { playing a video game) } \\
\text { and speed (while } \\
\text { crossing the street) }\end{array}$ & $\begin{array}{l}\text { field observations by } \\
\text { video recording }\end{array}$ & $\begin{array}{c}\text { children } \\
\text { (aged } 4 \text { years } \\
3 \text { months-10 years) }\end{array}$ & $\begin{array}{l}\text { presence/absence of } \\
\text { parent } \\
\text { distraction (seconds) } \\
\text { speed }(\mathrm{m} / \mathrm{s})\end{array}$ \\
\hline Nasar et al., 2008 [62] & $\begin{array}{l}\text { mobile telephones } \\
\text { distracted attention and } \\
\text { pedestrian safety }\end{array}$ & $\begin{array}{l}\text { field observations by } \\
\text { video recording }\end{array}$ & $\begin{array}{c}60 \text { pedestrians (1st } \\
\text { study) and } 127 \text { ( } 2 \text { nd } \\
\text { study) with different } \\
\text { ages }\end{array}$ & $\begin{array}{l}\text { percentage who walked } \\
\text { with or without mobile } \\
\text { phone or i-pod }\end{array}$ \\
\hline Stavrinos et al., 2009 [63] & $\begin{array}{l}\text { influence of talking on } \\
\text { a cell phone for } \\
\text { pediatric pedestrian } \\
\text { injury risk }\end{array}$ & $\begin{array}{l}\text { field observations by } \\
\text { video recording; } \\
\text { statistical and } \\
\text { prediction analysis }\end{array}$ & 10 to 11 years old & $\begin{array}{l}\text { distraction (seconds) } \\
\text { speed }(\mathrm{m} / \mathrm{s})\end{array}$ \\
\hline Zhuang and $\mathrm{Wu}, 2011$ [64] & $\begin{array}{l}\text { pedestrians' crossing } \\
\text { behaviors and safety at } \\
\text { unmarked } \\
\text { roadway }\end{array}$ & $\begin{array}{l}\text { field observations by } \\
\text { video recording; }\end{array}$ & $\begin{array}{l}254 \text { pedestrians at } \\
\text { unmarked roadway } \\
\text { (different age) }\end{array}$ & $\begin{array}{c}\text { trajectory of } \\
\text { pedestrians by means } \\
\text { of video cameras, } \\
\text { potential distractors } \\
\text { before and after } \\
\text { crossing) }\end{array}$ \\
\hline Schwebel et al., 2012 [65] & $\begin{array}{l}\text { influence of talking on } \\
\text { the phone, texting and } \\
\text { listening to music on } \\
\text { pedestrian safety }\end{array}$ & $\begin{array}{l}\text { field observations by } \\
\text { video recording }\end{array}$ & $\begin{array}{l}138 \text { university students } \\
\text { walked across an } \\
\text { interactive, } \\
\text { semi-immersive virtual } \\
\text { pedestrian street. }\end{array}$ & $\begin{array}{c}\text { demographic data, } \\
\text { frequency of walking } \\
\text { and frequency of media } \\
\text { use. }\end{array}$ \\
\hline
\end{tabular}


Table 3. Cont.

\begin{tabular}{|c|c|c|c|c|}
\hline Source & Objective & Method & Target Group/Sample & $\begin{array}{l}\text { Parameters } \\
\text { Analyzed }\end{array}$ \\
\hline Ortiz et al., 2017 [66] & $\begin{array}{c}\text { distraction and road } \\
\text { user behavior }\end{array}$ & $\begin{array}{l}\text { observational pilot } \\
\text { study across } \\
\text { intersections }\end{array}$ & $\begin{array}{l}4871 \text { road users } \\
\text { (different ages) }\end{array}$ & $\begin{array}{l}\text { type of distraction (e.g., } \\
\text { mobile phone), gender, } \\
\text { age, location and } \\
\text { conflict indicators. }\end{array}$ \\
\hline Tapiro et al., 2018 [26] & $\begin{array}{c}\text { the effect of } \\
\text { environmental } \\
\text { distractions on child } \\
\text { pedestrians' crossing } \\
\text { behavior }\end{array}$ & $\begin{array}{l}\text { field observations by } \\
\text { video recording }\end{array}$ & $\begin{array}{l}\text { elementary school-aged } \\
\text { children (52 units) }\end{array}$ & $\begin{array}{c}\text { distractors-three types } \\
\text { of audio distractions }\end{array}$ \\
\hline Osborne et al., 2020 [67] & $\begin{array}{l}\text { the effectiveness of } \\
\text { potential current and } \\
\text { future countermeasures } \\
\text { from the end-user } \\
\text { perspective }\end{array}$ & $\begin{array}{l}\text { interviews and a } \\
\text { focus group }\end{array}$ & $\mathrm{n} / \mathrm{a}$ & $\begin{array}{c}\text { behavioral; } \\
\text { legislation/regulation; } \\
\text { infrastructure } \\
\text { initiatives and } \\
\text { technological advances }\end{array}$ \\
\hline Liu et al., 2021 [68] & $\begin{array}{l}\text { the effect of distraction } \\
\text { due to mobile phone } \\
\text { use on pedestrian } \\
\text { reaction time to the } \\
\text { pedestrian signal. }\end{array}$ & $\begin{array}{c}\text { a multilevel } \\
\text { mixed-effects } \\
\text { accelerated failure } \\
\text { time (aft). } \\
\text { survival model }\end{array}$ & $\mathrm{n} / \mathrm{a}$ & $\begin{array}{c}\text { demographic attributes, } \\
\text { distraction } \\
\text { characteristics and } \\
\text { environment-related } \\
\text { parameters. }\end{array}$ \\
\hline
\end{tabular}

\section{Pedestrian Behavior-Prediction Models-Literature Review}

The modeling of pedestrian behavior is an important tool in better understanding the influential factors, as it enables the analysis of a large number of scenarios and potentially dangerous interactions, without affecting the actual system and endangering the safety of pedestrian movements.

Pedestrian movement across the pedestrian crossing, including reaction time and movement in the conflict zone, although these two phases can be observed uniquely due to different influential parameters and their significance $[69,70]$, was analyzed separately. Pedestrians play an important role in urban mobility, but a smaller number of studies deal with research on pedestrian behavior compared to driver behavior research. The study [71] presents the results of research on the total reaction time of drivers in real traffic conditions. Jurecki and Stańczyk [72] investigated the reaction time of drivers to an accident situation involving pedestrians entering in the road area from the left or right side. Driver reaction times have been shown as a function of time-to-collision, which characterizes accident risk situations. Models have been developed to predict the reaction time of drivers in different circumstances. Mehmood and Easa [73] developed driver reaction-time models for car-following analysis based on human factors. The reaction time was classified as brake-reaction time and acceleration /deceleration reaction time. The kinematic conditions introduced urgency and expectancy based on the braking behavior of the lead vehicle at different speeds and spacing. The influence of the mobile phone as a distractor on the reaction time of drivers is the subject of several research studies. The subject of the study [74] was the reaction times of young drivers to a traffic event originating in their peripheral vision whilst engaged in a mobile phone conversation. The reaction times of drivers were more than $40 \%$ longer in the distracted condition compared to the non-distracted condition. A study [75] that analyzed and modeled the effects of mobile phone distraction upon the reaction time of Indian drivers belonging to three different age groups had similar results. Two different types of hazardous events-a pedestrian crossing event and a road crossing event by parked vehicles-were included for measuring drivers' reaction times. The developed models showed that in the case of the pedestrian crossing event, the phone-use tasks-simple conversation, complex conversation, simple texting, and complex texting-caused 40\%, 95\%, 137\%, and 204\% increments in the reaction 
times, and in the case of the road crossing event by parked vehicles, the tasks caused $48 \%$, $65 \%, 121 \%$, and $171 \%$ increments in reaction times. The study [76] examined the influence of time pressure on the reaction times of the drivers measured for two different perilous events (pedestrians crossing and obstacle overtaking). The survival analysis technique was used to model the effects of time pressure and driver characteristics on the reaction times of the drivers.

Pedestrians as a group of traffic users have the largest age range, from children to the elderly, and each subgroup has its own specifics. Research shows that the analysis of pedestrian traffic safety is a very complex task, because many factors have an impact on pedestrian behavior. Modeling of pedestrian behavior is an important tool in better understanding influential factors, as it enables the analysis of a large number of scenarios and potentially dangerous interactions, without affecting the actual system and endangering the safety of pedestrian movements. A model for predicting the impact of a mobile phone on pedestrian reaction time to the pedestrian signal was developed by Liu et al. [68]. Auditory and visual distractions increase pedestrian reaction time by $67 \%$ and $50 \%$ on average, respectively.

\subsection{Overview of Existing Models for Pedestrian and Child-Pedestrian Behavior at Crosswalks}

In order to analyze pedestrian behavior in the conflict zones of different types of intersections, the most commonly applied method is modeling at the microsimulation level. Zeng et al. [77] use an adjusted social force model in analyzing the influential parameters of pedestrian behavior at signalized intersections. Modeling results show good results in predicting individual trajectory and collision-avoidance behavior with conflicting vehicles. Gruden et al. [78] achieved an improvement in the reliability of microsimulation models for pedestrians by applying neural networks in the model calibration process.

Gitelman et al. [79] observed child-pedestrian behaviors at crosswalks of urban intersections, aiming to characterize their behavior patterns and identify risk factors that may lead to injury. Multivariate logistic regression models were adjusted to identify factors associated with crossing on red and with non-checking vehicle traffic at unsignalized crosswalks. The results showed that in addition to the age of children, different attention distractors have a significant impact on children's risky behavior in traffic.

Meir and Oron-Gilad [23] investigated pedestrians' hazard-perception skills in complex traffic scenes, and the results showed their dependence on contextual variables and risk perception. The simple and usual design of the conflict zone, with less additional environmental content, results in greater attention in the analysis of the current traffic situation. According to the results of the study, children and teens are highly influenced by the distraction of attention. The creation of models generating different traffic scenarios and predicting the behavior of pedestrians and of individual groups of vulnerable traffic users, such as children, is vital for successful testing of new technologies, such as the applicability of autonomous vehicles [80].

The research of [81] analyzes the relationship between age and pedestrian speed, considers pedestrian speed on sidewalks in real conditions, and focuses on users walking not alone but within a flow, in conditions where a pedestrian interacts with other pedestrians. The analysis shows that there is not a linear relationship between speed and age, but it is better to consider a polynomial model between the mean individual pedestrian speed, mean walking speed, and age class.

As part of the research of [82], pedestrians on sidewalks were subdivided for user type (isolated, single, group). The results showed that the mean walking pedestrian speed depends on user type, age group, gender, and urban context. Multiple regression models obtained for the different pedestrian types were compared to understand the differences in speeds, underlining that pedestrian interferences play a significant role in defining behavior, and therefore, speed. 
The research conducted in Taiwan [83] is based on the collection of data at signalized intersections, analyzing the influencing factors in the individual speed of pedestrians using regression analysis.

The behaviors of pedestrians at signalized crosswalks are different from ordinary walking spaces, and they are influenced by signal indication, potential conflicts with vehicles and intersection geometries. One of the characteristics of pedestrian behavior at crosswalks is a possible sudden speed change while crossing (acceleration/deceleration), which may lead to hazardous situations. The occurrence of speed-change events is described by a discrete choice model as a function of the necessary walking speed to complete crossing before the red interval ends, current speed, and the presence of turning vehicles in the conflict area. The amount of speed change before and after the event is modeled using regression analysis, and a Monte Carlo simulation is applied for the entire speed profile of the pedestrians [84]. The comparison with the empirical data showed that the model was successful in representing the observed crossing time-distributions with better accuracy compared to the crossing time-distributions that are estimated based on constant crossing speed.

In one study [49], a model was formulated to explore the variation and examine the influential factors on pedestrian crossing speed at the signalized intersections. The correlation analysis depicts that the pedestrian crossing speed has a significant negative correlation with the crosswalk width, the crosswalk length, the width of the pedestrian island, the classification of road, average traffic flow, and average pedestrian delay, whereas the availability of separate bicycle paths at intersections is positively correlated. The variation in the percentile crossing speeds exists among different age groups, group sizes and crossing patterns, but the statistical analysis indicates no significant difference between genders. The model was developed using the Stepwise Linear regression (MLR) and, as variables, the width of the crosswalk, the width of the pedestrian island, and the average depth of delay were included. The reliability of the model is $70 \%$.

Russo et al. [85] analyzed in their research over 3000 pedestrian video data collected at four signalized intersections in New York and Arizona, and the study provides insight into factors associated with distracted walking, pedestrian violations, and walking speed. The ordinary least squares (OLS) regression model was estimated to analyze factors affecting walking speeds. The results of the OLS regression walking speed model showed that talking and texting while walking was not statistically significantly associated with walking speed, indicating that pedestrians may be accustomed to walking while talking or texting, and do not significantly slow (or increase) their walking speeds while engaging in these activities. The study also showed that pedestrians wearing headphones exhibited faster walking speeds, and that pedestrians walking in groups of two or more exhibited slower walking speeds, among other results.

The study [86] aimed to carry out microscopic-level research on pedestrian crossing speed and waiting time at intersections in Dhaka. Results of the multiple regression model show that the crossing speed of pedestrians was associated with intersection control type, gender, age, crossing type, crossing group size, compliance behavior with control direction, and crossing location. The results of the study showed that females, children, and old pedestrians had a lower crossing speed than male, young, and adult pedestrians, respectively, and pedestrians who crossed the road alone and who did not carry any baggage had higher speeds.

Unlike research and models that deal with the behavior of the general pedestrian population in the conflict zone, the authors of this article developed models that model the behavior of child pedestrians in the conflict zone of signalized crosswalks [13]. Children, as a special group of traffic users within the pedestrian flow, have their own specifics and deviations in behavior [12] and reaction time [87] in relation to adult traffic users.

Table 4 shows that regression models predominate as types of models, and that different studies and models of pedestrian behavior have identified similar or the same influential parameters on the speed of pedestrian movement at signalized pedestrian crosswalks at intersections. Analyses show that for child-pedestrian speed, some additional 
parameters were identified, such as the total number of children at the crosswalk, presence of adult supervision and running without prior safety check.

Table 4. Individual pedestrian speed prediction models-overview of available papers.

\begin{tabular}{|c|c|c|c|c|}
\hline Source & Objective & Method & $\begin{array}{c}\text { Target } \\
\text { Group/Sample }\end{array}$ & $\begin{array}{c}\text { Parameters } \\
\text { Analyzed }\end{array}$ \\
\hline $\begin{array}{c}\text { Chang, C.-Y. et al., } \\
2011 \text { [83] }\end{array}$ & regression model & $\begin{array}{c}\text { field research/ } \\
\text { signalized crosswalks }\end{array}$ & $\begin{array}{c}\text { general } \\
\text { population/5235 }\end{array}$ & $\begin{array}{c}\text { gender, temperature, weather, number } \\
\text { of lanes, signal type, group of } \\
\text { pedestrians, and pedestrian phase } \\
\text { length }\end{array}$ \\
\hline $\begin{array}{l}\text { Pinna, F.; Murrau, } \\
\text { R., } 2017 \text { [82] }\end{array}$ & $\begin{array}{l}\text { multiple } \\
\text { regression model }\end{array}$ & $\begin{array}{l}\text { field research/ } \\
\text { sidewalks }\end{array}$ & $\begin{array}{l}\text { general population } \\
\text { subdivided into } \\
\text { user types: isolated, } \\
\text { single and } \\
\text { groups / } 4800\end{array}$ & age group, gender, and urban context \\
\hline $\begin{array}{c}\text { Pinna, F.; Murrau, } \\
\text { R., } 2018 \text { [81] }\end{array}$ & $\begin{array}{l}\text { statistical analysis } \\
\text { and polynomial } \\
\text { model }\end{array}$ & $\begin{array}{l}\text { a survey and field } \\
\text { research/ } \\
\text { sidewalk }\end{array}$ & $\begin{array}{c}\text { general } \\
\text { population/2794 }\end{array}$ & age class and mean walking speed \\
\hline $\begin{array}{l}\text { Russo B.J. et al., } \\
2018 \text { [85] }\end{array}$ & $\begin{array}{l}\text { ordinary least } \\
\text { squares regression } \\
\text { model }\end{array}$ & $\begin{array}{c}\text { field research/ } \\
\text { signalized crosswalks }\end{array}$ & $\begin{array}{c}\text { general population/ } \\
3038\end{array}$ & $\begin{array}{l}\text { crossing length, "walk" time, } \\
\text { "flashing don't walk" time, cycle } \\
\text { length, pedestrian push button } \\
\text { equipped, distractions (talking or } \\
\text { texting on mobile phone, headphones, } \\
\text { other), cross with or against traffic, } \\
\text { gender, age, group size }(1,2,3-4,5 \text { or } \\
\text { more), opposing pedestrians }(0,1,2 \text { or } \\
\text { more), waiting time }(0 \mathrm{~s}, 1 \mathrm{~s} \text { or more })\end{array}$ \\
\hline $\begin{array}{c}\text { Bansal, A. et al., } \\
2019 \text { [49] }\end{array}$ & $\begin{array}{l}\text { stepwise } \\
\text { regression model }\end{array}$ & $\begin{array}{c}\text { field research/ } \\
\text { signalized crosswalks }\end{array}$ & $\begin{array}{c}\text { general } \\
\text { population/994 }\end{array}$ & $\begin{array}{l}\text { crosswalk width, crosswalk length, } \\
\text { width of the pedestrian island, } \\
\text { classification of road, average traffic } \\
\text { flow, average pedestrian delay, } \\
\text { availability of separate bicycle paths }\end{array}$ \\
\hline $\begin{array}{l}\text { Zafri, N.M. et al., } \\
2019 \text { [86] }\end{array}$ & $\begin{array}{l}\text { multiple linear } \\
\text { regression model }\end{array}$ & $\begin{array}{l}\text { field } \\
\text { research/different } \\
\text { types of crosswalks } \\
560 \text { samples }\end{array}$ & $\begin{array}{c}\text { general } \\
\text { population/560 }\end{array}$ & $\begin{array}{c}\text { intersection control type, gender, age, } \\
\text { crossing type, crossing group size, } \\
\text { baggage handling, mobile usage, } \\
\text { compliance behavior with control } \\
\text { direction, crossing location, vehicle } \\
\text { flow }\end{array}$ \\
\hline $\begin{array}{l}\text { Ištoka Otković, I. } \\
\text { et al., } 2021 \text { [13] }\end{array}$ & $\begin{array}{l}\text { neural network } \\
\text { model }\end{array}$ & $\begin{array}{l}\text { field research } \\
\text { / signalized } \\
\text { crosswalks }\end{array}$ & $\begin{array}{l}\text { child pedestrians / } \\
\qquad 300+180\end{array}$ & $\begin{array}{c}\text { age group, gender, disabilities, } \\
\text { movement in a group, supervision by } \\
\text { adults, talking or texting on mobile } \\
\text { phone, number of children and total } \\
\text { number of pedestrians on crosswalk, } \\
\text { length and width of crosswalk, green } \\
\text { time for pedestrians, traffic signal } \\
\text { cycle, running }\end{array}$ \\
\hline $\begin{array}{l}\text { Ištoka Otković, I. } \\
\text { et al., } 2021 \text { [13] }\end{array}$ & $\begin{array}{l}\text { multiple linear } \\
\text { regression model }\end{array}$ & $\begin{array}{c}\text { field research/ } \\
\text { signalized crosswalks }\end{array}$ & $\begin{array}{l}\text { child pedestrians / } \\
\quad 300+180\end{array}$ & $\begin{array}{l}\text { age group, gender, disabilities, } \\
\text { movement in a group, supervision by } \\
\text { adults, talking or texting on mobile } \\
\text { phone, number of children and total } \\
\text { number of pedestrians on crosswalk, } \\
\text { length and width of crosswalk, green } \\
\text { time for pedestrians, traffic signal } \\
\text { cycle, running }\end{array}$ \\
\hline
\end{tabular}


Table 5 shows the results of model reliability and validation. Model reliability is the accuracy of the model on the database on which the model was developed, and model validation is the accuracy of the model applied on the new datasets.

Table 5. Model reliability and validation-overview of available models.

\begin{tabular}{|c|c|c|c|}
\hline Source & Model & Model Reliability & Validation of Model \\
\hline Chang, C.-Y. et al., 2011 [83] & regression model & $\mathrm{R}^{2}=0.179$ & $\mathrm{n} / \mathrm{a}$ \\
\hline Pinna, F.; Murrau, R., 2017 [82] & $\begin{array}{l}\text { multiple } \\
\text { regression model }\end{array}$ & $\begin{array}{c}\text { isolated } \\
\mathrm{R}^{2}=0.79 ; \\
\text { RMSPE }=0.0607 \\
\text { Single } \\
\mathrm{R}^{2}=0.76 ; \\
\text { RMSPE }=0.0698 \\
\text { Groups } \\
\mathrm{R}^{2}=0.93 ; \mathrm{RM}+\mathrm{SPE}=0.0375\end{array}$ & $\begin{array}{c}\text { isolated } \\
\mathrm{R}_{\mathrm{V}}^{2}=0.81 ; \text { RMSPEv }=0.0652 \\
\quad \text { Single } \\
\mathrm{R}_{\mathrm{v}}^{2}=0.88 ; \text { RMSPEv }=0.0414 \\
\quad \text { Groups } \\
\mathrm{R}_{\mathrm{V}}^{2}=0.98 ; \operatorname{RMSPEv}=0.0586\end{array}$ \\
\hline Pinna, F.; Murrau, R., 2018 [81] & $\begin{array}{l}\text { statistical analysis and } \\
\text { polynomial model }\end{array}$ & $\begin{array}{c}\mathrm{Rc}^{2}=0.8711 \\
\mathrm{ME}=0.0253 \\
\mathrm{MPE}=0.0259 \\
\mathrm{RMSE}=0.0314 \\
\mathrm{RMSPE}=0.0320\end{array}$ & $\begin{array}{c}\mathrm{R}_{\mathrm{v}}^{2}=0.9694 \\
\mathrm{ME}=0.0256 \\
\mathrm{MPE}=0.0288 \\
\mathrm{RMSE}=0.0288 \\
\mathrm{RMSPE}=0.0321\end{array}$ \\
\hline Russo B. J. et al., 2018 [85] & $\begin{array}{l}\text { ordinary least squares } \\
\text { regression model }\end{array}$ & $\mathrm{R}^{2}=0.132$ & $\mathrm{n} / \mathrm{a}$ \\
\hline Bansal, A. et al., 2019 [49] & $\begin{array}{l}\text { stepwise } \\
\text { regression model }\end{array}$ & $\mathrm{R}^{2}=0.701$ & $\mathrm{n} / \mathrm{a}$ \\
\hline Zafri, N.M. et al., 2019 [86] & $\begin{array}{c}\text { multiple linear regression } \\
\text { model }\end{array}$ & $\mathrm{R}^{2}=0.391$ & $\mathrm{n} / \mathrm{a}$ \\
\hline
\end{tabular}

$\begin{array}{cc}\mathrm{R}^{2}=0.803 \\ \text { Ištoka Otković, I. et al., 2021 [13] } \quad \text { neural network model } & \mathrm{MASE}=0.098 \\ \mathrm{RMS} & \end{array}$
First validation $\mathrm{R}^{2}=0.819$

MAE $=0.129$

RMSE $=0.143$

Second validation $R^{2}=0.676$

MAE $=0.085$

RMSE $=0.101$

First validation $\mathrm{R}^{2}=0.497$

$\mathrm{MAE}=0.159$

RMSE $=0.217$

Second validation $\mathrm{R}^{2}=0.560$

$\mathrm{MAE}=0.313$

$\mathrm{RMSE}=0.343$

Table 5 shows that the reliability of the model expressed through the correlation coefficient $\left(\mathrm{R}^{2}\right)$ ranges from 0.179 to 0.98 , and the validation results show a correlation coefficient in the range from 0.497 to 0.98 .

\subsection{Models for Child-Pedestrian Reaction Time and Speed at the Signalized Intersection}

Separated models have been developed to predict the reaction time of children [87] and speeds of movement in the conflict zone [13]. One of the important goals for the development of a model for predicting the reaction time (as the first component) and the speed of movement in the conflict zone (as the second component of the pedestrian crossing procedure) is the analysis of influential parameters. The prediction model for children's reaction time in real traffic conditions [87] provided by the backpropagation-Ward net neural network, gave the correlation coefficient $\left(R^{2}\right) 0,90$, and the mean absolute error of prediction is $0.35 \mathrm{~s}$. A comparison of the measured reaction time of children and the 
prediction given by the model is shown in Figure 1a. Model validation was performed on a new set of measured data at the same intersection and at a new intersection with traffic lights. Validation of the model gave the correlation coefficient $\left(R^{2}\right) 0.85$, and the mean absolute error of prediction is $0.27 \mathrm{~s}$. Given that the observed neural network model has good correlation on the underlying database and generalization ability demonstrated in the validation data set, it makes sense to analyze the relative impact of input parameters as recognized by the neural network (Figure $1 \mathrm{~b}$ ).

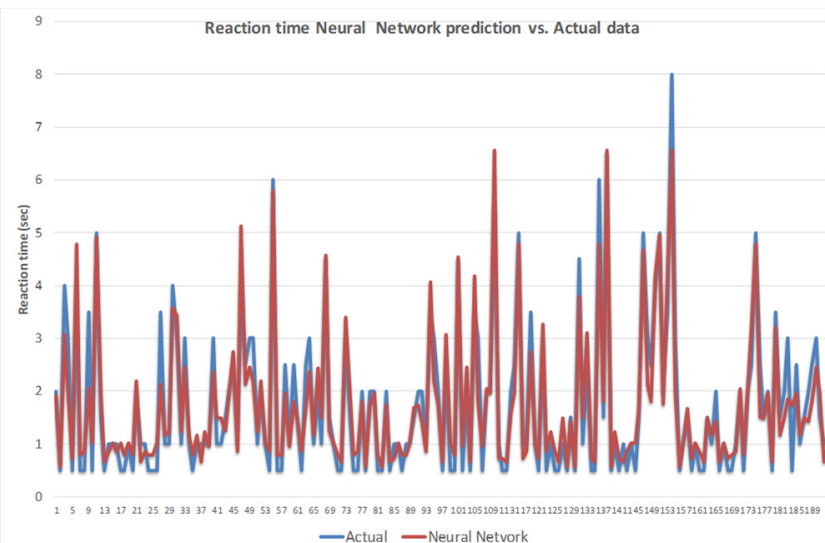

(a)

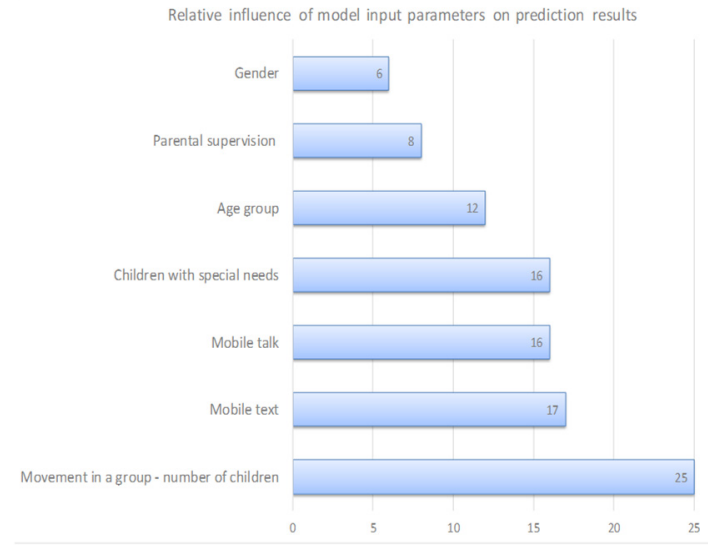

(b)

Figure 1. Comparison of modeled and measured children's reaction times (a) and the relative impact of input parameters as recognized by the neural network (b) (source: authors, processed from [87]).

The neural network analyses recognized movement in a group as the most influential parameter on the reaction time of the observed population of children. The next influential parameter is the distraction caused by using a mobile phone.

Models for predicting the speed of children in the conflict zone of the signalized intersection [13] were developed based on 300 measurements conducted in Osijek, Croatia, and validation was made on two databases: the first database was for the city of Rijeka, Croatia (100 measurements) and a second validation was made for the city of Enna, Italy (80 measurements). Two models for the speed of child-pedestrians at signalized pedestrian crosswalks were developed, validated, and compared: a model of a neural network and a model based on multiple linear regression.

Figure 2 shows a comparison of the prediction provided by the neural network model and linear regression model with the data measured in real traffic conditions.

As can be seen from Figure 2, the neural network model provided good accuracy for the environment for which it was developed (Osijek, Croatia), as well as for the two environments where the model was validated (Rijeka, Croatia; Enna, Italy). Basic model accuracy and validation indicators are shown in Table 5. The model based on multiple linear regression was also shown applicable in Rijeka, while the applicability indicators of the model were negative for Enna and the model should not be applied. Data on the correlation coefficient $\left(R^{2}\right)$ and the mean prediction error are visible in Table 5 .

A model that has shown its effectiveness both on a basic basis and on validation bases can offer a good insight into the relative influences of the model input parameters on the prediction result. A comparison of the relative influence of individual input parameters of the model (Table 4) on the prediction of crossing speed of pedestrian children for the neural network model and the linear regression model is shown in Figure 3. 


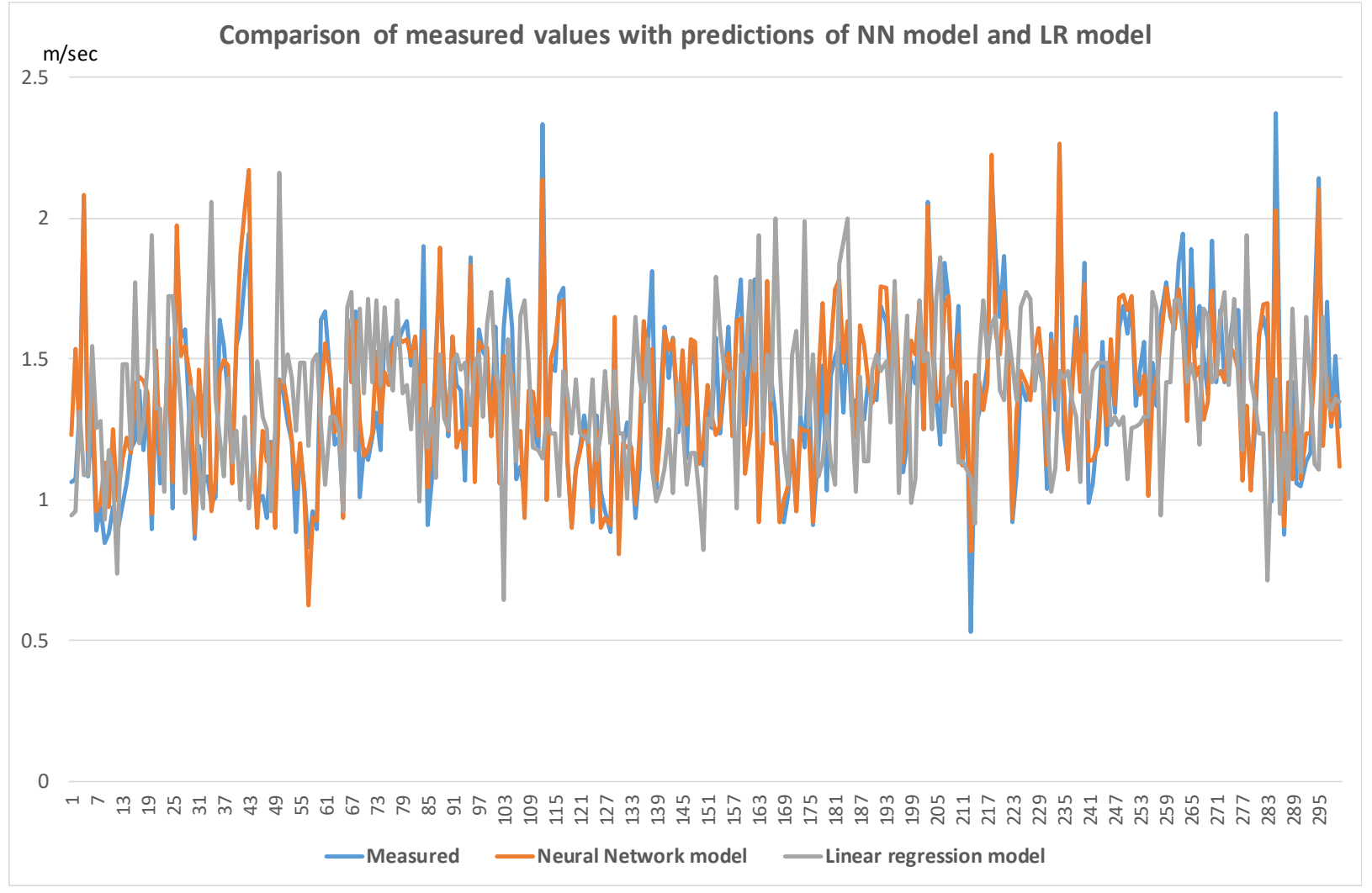

Figure 2. Comparison of measurements and prediction of NN and LR models for the crossing speed (source: authors, processed from [13]).

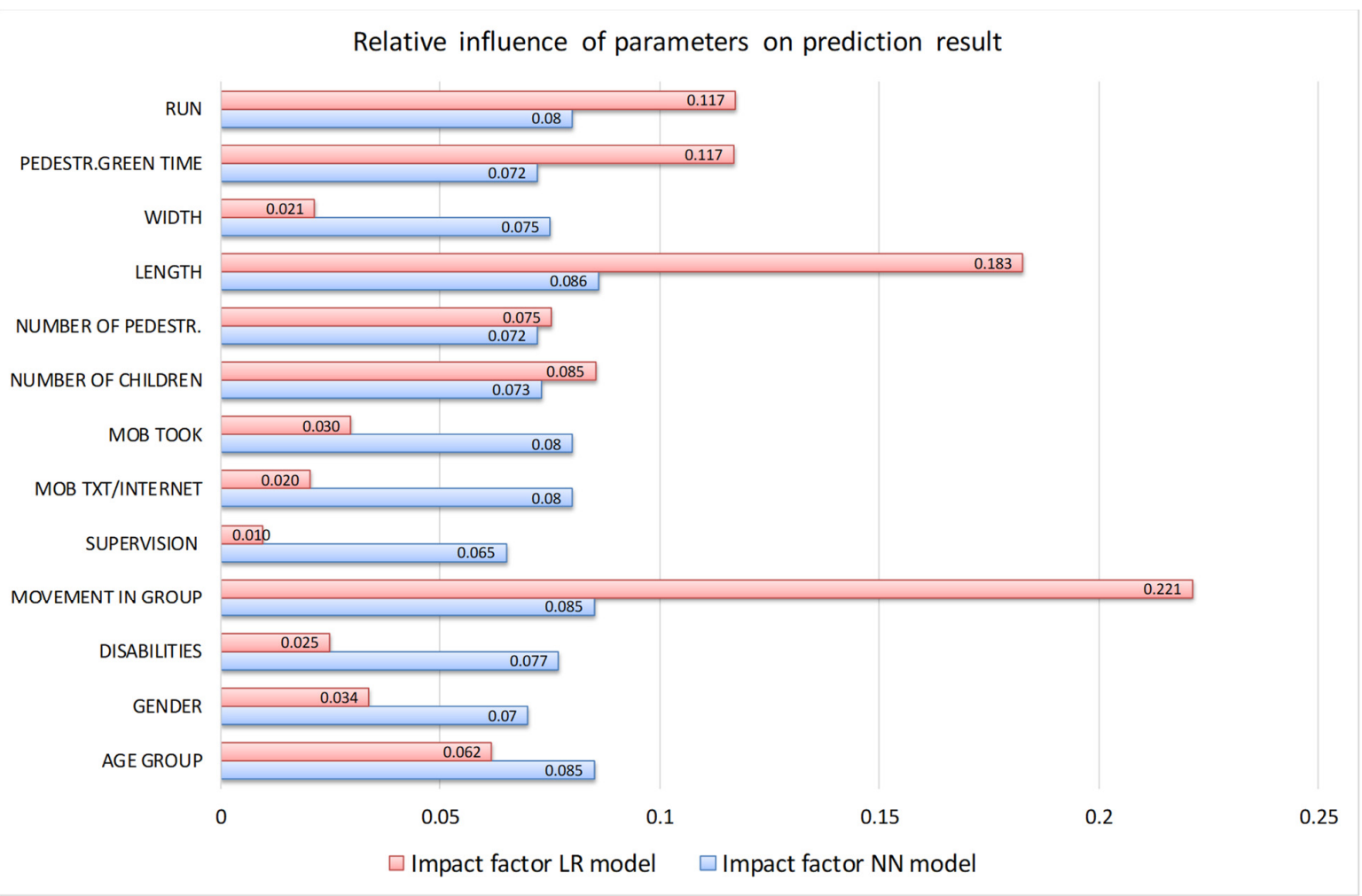

Figure 3. Relative influence of parameters on crossing speed prediction for both observed models (source: authors, processed from [13]). 
It is interesting to see from Figure 3 that both models recognize the movement in a group as the largest distractor for the speed of movement in a conflict zone. According to the LR model, the use of mobile phones is a significantly smaller distractor, while the neural network recognizes the impact of mobile phones as a significant distractor in the observed population of children. Comparing Figures $1 \mathrm{~b}$ and 3 , it can be seen that the use of mobile phones that occupy visual attention is the second most influential parameter in terms of importance regarding children's reactions. The impact of this distractor should be considered in the context that in the observed population of children in Croatia, children who used a mobile phone made up less than $10 \%$ of the total sample. This problem becomes significant for older children and adolescents. Research conducted on the student population with eye-tracking equipment has shown that the use of mobile phones is a distractor that has an impact on reaction time more, but also on crossing speed in the conflict zone of signalized [69] and unsignalized [70] pedestrian crosswalks.

A good prediction of neural network models based on the basic database and validation databases gave the authors the opportunity to analyze how the neural network recognizes the impact of a combination of two variables on the prediction result. Using the prediction function given by the neural network, we made an analysis of the influence of the infrastructural parameters, width, and length of the pedestrian crosswalk, and the results are shown in Figure 4a. The impact of the combination of pedestrian crosswalk length and duration of green time for pedestrians is shown in Figure $4 \mathrm{~b}$. The results of this analysis cannot be taken as realistic field conditions, because all other input parameters had selected constant values, which gives the observed input variables the opportunity to show their influence on the dependent variable. This analysis gives us an insight into the correlations as recognized by the neural network to assess whether correlations are expected.

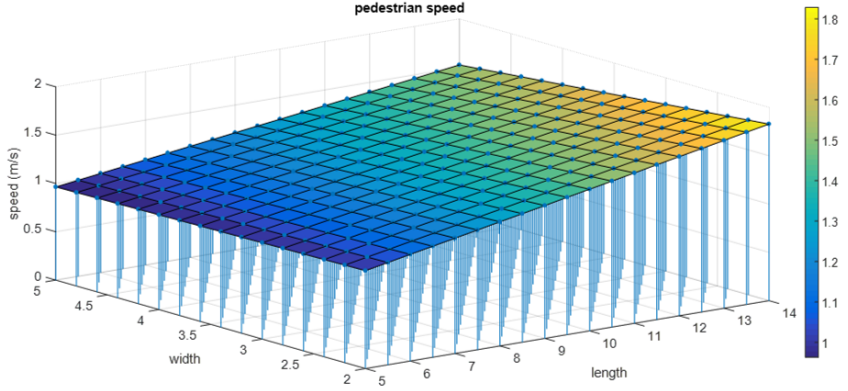

(a)

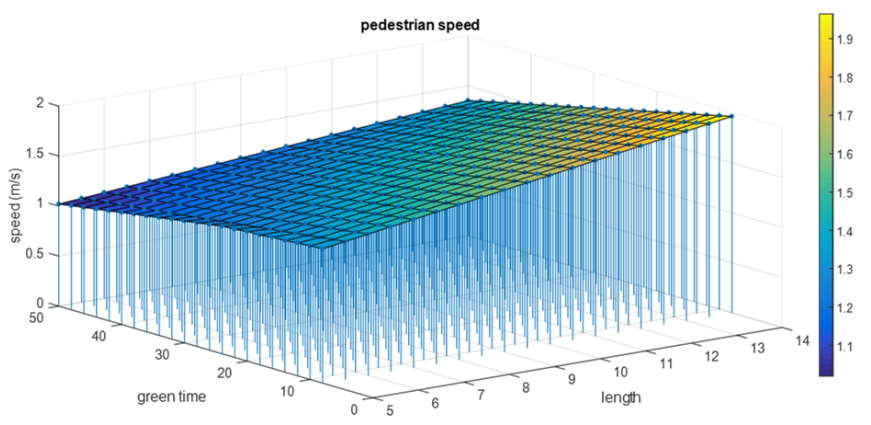

(b)

Figure 4. Influence of infrastructural parameters (a) and duration of green time for pedestrians (b) on crossing speed according to the neural network.

It can be seen from Figure $4 \mathrm{a}$ that the neural network recognizes positive correlation between pedestrian crosswalk length and crossing speed. For a longer pedestrian crosswalk, the crossing speed is higher, which is the expected result. According to Figure $4 \mathrm{a}$, the width of a pedestrian crosswalk has less influence than length on crossing speed, and crossing speed and width have a negative correlation, which is also expected. It can be presumed that a narrower pedestrian crosswalk gives less sense of security to pedestrians. According to Figure $4 b$, the neural network recognizes a negative correlation between the duration of the green light for pedestrians and children's pedestrian crossing speed. Longer green signal duration promotes lower crossing speed, which is an expected impact.

Figure 5 shows the influence of age and group size (from one child to five children) separately for girls (Figure 5a) and for boys (Figure 5b).

In a diagram showing girls (Figure 5a), older girls move faster and move faster independently than in a group, which is the expected result. Interestingly, boys (Figure 5b) aged 14-15 years move more slowly than boys aged 12-13 years, which, given the impact of puberty, would also be considered an expected impact on prediction outcome. 


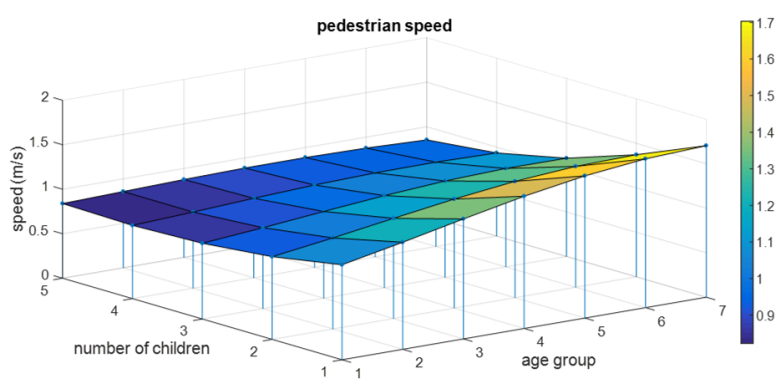

(a)

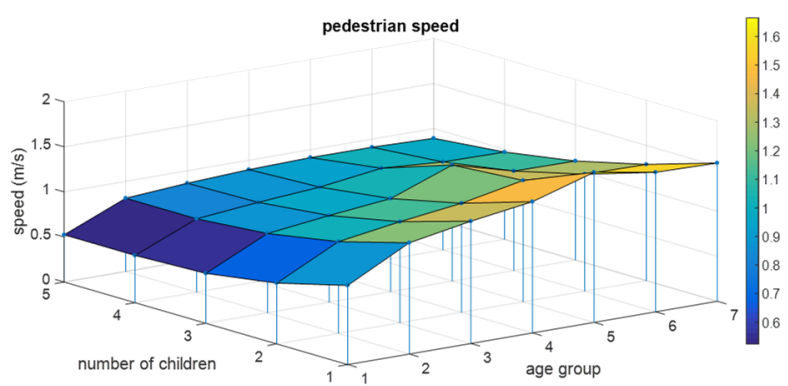

(b)

Figure 5. Influence of age and group size for girls (a) and for boys (b) on crossing speed according to the neural network.

\section{Discussion and Conclusions}

In this paper, an extensive overview was undertaken of the available research, mostly conducted in the last decade, on children's road traffic safety.

The analyses were directed towards the examination of parameters, models, and methods used to analyze the safety of children in urban areas in the areas of pedestrian crosswalks where they are very prone to potential conflict with vehicles. The impact of children's cognitive development and excellent functions on their traffic behavior and safety has not been analyzed in detail.

It turned out to be a topic that is being researched all over the world, but in recent years more intensively in countries with a more pronounced problem of road traffic safety and intensive pedestrian traffic (e.g., China, India).

A review of the available papers shows that the most commonly used methods of data collection are experiments conducted in real traffic conditions, with or without the knowledge of children who participate in them. More recently, virtual reality methods have also been used to faithfully depict real traffic situations in a completely safe environment for children. With all methods, except recording children in real traffic conditions without their knowledge, the question of the reliability of the obtained results can be raised.

The analysis of research on children's road traffic safety could lead to the conclusion that traffic systems (infrastructure) should be adapted to the needs of children. However, the relationship between the age and gender of the child and their behavior in traffic does not show universal characteristics, and outcomes depend on locally conditioned circumstances, such as traffic system and culture, density of built-up areas, and other factors.

Research on the impact of sociodemographic factors (gender, age, supervising, and group movement) on children's crossing behavior has been repeatedly undertaken in various studies. Road-crossing performance behavior improves with age, but only up to 12 or 13 years; after this age, children are as cognitively capable as adults, but still show signs of risky behavior in traffic. Differences in children's behavior with regard to gender are expressed to a much lesser extent in relation to the age difference, although some studies confirmed that boys behave in riskier ways than girls. In addition to the gender and age of the children, the significant impact of parental or adult supervision was also confirmed, as well as group movements; namely, supervised children, as well as children in a group, move more slowly at pedestrian crosswalks and show somewhat less risky behavior compared to individually crossing children.

Studies are much more oriented toward establishing the characteristics of children and their behavior on their traffic safety than on analyses of traffic infrastructure used by children.

From the analysis of existing research, it can be concluded that the design of pedestrian crosswalks and their arrangement, as well as facilities (traffic signs, advertisements) placed within the zone of pedestrian crosswalks used independently by children, should be adapted to meet the specific needs of pedestrian children to reduce the risk of their injury.

If the speed at which children cross the street is considered as an indicator of the behavior of children in conflict zones of pedestrian crosswalks, it turns out that trends, when 
traffic infrastructure elements are considered, are similar to those of adult pedestrianslonger walking paths and shorter green walking times result in faster road crossing. Due to the fact that children are still undergoing physical and cognitive development, this phenomenon can pose a potential danger to pedestrian children.

Research conducted in laboratory conditions (in Israel) shows that children in complex infrastructural situations tend to be hesitant when making the decision to cross the street, which can be considered positive, but indicates the need for additional training in traffic skills.

The analysis of the models for prediction of pedestrian behavior in pedestrian crossing zones detected a number of parameters that have an impact on the speed of pedestrian movement. Models are typically developed using regression analysis for the general population, including younger ages. The only models developed exclusively for the child population (5-15) are those developed by the author. Analysis of the parameters shows that they are similar or the same when it comes to children in relation to the general population.

The identified parameters specific to child movement are the total number of children at the crosswalks, adult supervision and running without prior security check.

The analysis of the sample and the reliability of the available models shows that although the models developed for the general population are generally based on a larger sample, their reliability is lower than that obtained for the child movement model. The reason for this may be the homogeneity of the sample and the collected data, given that this is a group of more similar characteristics. These points need to be considered in other specific groups (such as the elderly) in order to predict their behavior as accurately as possible; in this case, speed as an input parameter for the design of pedestrian crosswalks.

Models developed in Croatia and Italy for the child population confirmed the local conditionality of certain parameters-the model based on the neural network method proved to be more widely applicable, while the model developed by regression analysis is less accurate, or not applicable with sufficient reliability outside the environment in which it was developed. This is why the models developed for one city are suggested just for the preliminary design in different locations, and adjustments are needed if their full implementation is undertaken.

The application of eye-tracking equipment in the study of pedestrian safety parameters opens a new area of research, and studies conducted on the population of pedestrian children in China and the student population in Slovenia may be a motivation for a similar approach with child pedestrians in different traffic circumstances-signalized and nonsignalized crosswalks, as well as roundabouts in different urban environments.

And finally, the last two years of the COVID-19 pandemic changed urban traffic notably - public transport became less used, there is now less motorized traffic because some work activities are organized on-line from home, people have been noticed walking less often in groups, and there is a great increase in micro-mobility modes of traffic. When children are considered, in the last two years they have had less opportunity to develop their traffic competencies, because they stayed more at home or in the company of parents or other adults (lock-down, self- isolation and on-line classes). In future research, it will be important to thoroughly investigate how these life changes manifest in children's traffic behavior, and consequently their traffic safety.

Author Contributions: Conceptualization, I.I.O., A.D.-T. and S.Š.; methodology, A.D.-T. and I.I.O.; software, I.I.O.; validation, I.I.O.; formal analysis, A.D.-T., I.I.O., S.Š. and T.C.; investigation, A.D.-T., I.I.O., S.Š. and T.C.; resources, I.I.O. and A.D.-T.; writing—original draft preparation, A.D.-T., I.I.O., S.Š. and T.C.; writing - review and editing, A.D.-T. and S.Š.; visualization, I.I.O. and S.Š.; supervision, A.D.-T.; project administration, A.D.-T. and I.I.O. All authors have read and agreed to the published version of the manuscript.

Funding: This research received no external funding.

Institutional Review Board Statement: The study was conducted according to the guidelines of the Declaration of Helsinki and approved by the Ethics Committee of Josip Juraj Strossmayer University of Osijek, Faculty of Civil Engineering and Architecture, reference number 2158-77-18-21-01, issued 
for the research within the bi-lateral Croatian-Slovenian project "Development of a prediction model of pedestrian children behavior in the urban transport network".

Informed Consent Statement: Informed consent was obtained from all subjects involved in the study.

Data Availability Statement: Data collected through research presented in the paper are available on request from the corresponding authors. Data are not publicly available because their use was approved for particular scientific project.

Acknowledgments: The authors would like to acknowledge that this research was supported by the international bilateral Croatian-Slovenian project "Development of prediction model of pedestrian children's behavior in the urban transport network" and by the project "Transport infrastructure in the function of sustainable mobility" (uniri-tehnic-18-143-1289) supported by the University of Rijeka, Croatia.

Conflicts of Interest: The authors declare no conflict of interest.

\section{References}

1. Road Safety Annual Report. 2020. Available online: https://www.itf-oecd.org/sites/default/files/docs/irtad-road-safetyannual-report-2020_0.pdf (accessed on 1 December 2021).

2. Mobility \& Transport-Road Safety. Available online: https://ec.europa.eu/transport/road_safety/statistics-and-analysis/dataand-analysis/annual-statistical-report_en (accessed on 1 December 2021).

3. Dekra. Available online: https:/ / www.dekra-roadsafety.com/media/dekra-evs-report-2019-en-92-0509.pdf (accessed on 1 December 2021).

4. Narodne-Novine. Available online: https://narodne-novine.nn.hr/clanci/sluzbeni/2011_05_59_1321.html (accessed on 5 December 2021). (In Croatian).

5. Ministarstvo Unutarnjih Poslova. Available online: https://mup.gov.hr/UserDocsImages/dokumenti/bilteni/Bilten_o_ sigurnosti_cestovnog_prometa_2020.pdf (accessed on 5 December 2021). (In Croatian)

6. STAT. Incidenti Stradali. Anno. 2017. Available online: https://www.istat.it/it/files//2018/07/Incidenti-stradali_2017.pdf (accessed on 20 November 2019). (In Italian).

7. Shaw, B.; Bicket, M.; Elliott, B.; Fagan-Watson, B.; Mocca, E.; Hillman, M.; Fagan-Watson, B. Children's Independent Mobility: An International Comparison and Recommendations for Action. London Policy Studies Institute. 2015. Available online: http:/ / www.psi.org.uk/children_mobility (accessed on 1 December 2021).

8. Luo, H.; Yang, T.; Kwon, S.; Zuo, M.; Li, W.; Choi, I. Using virtual reality to identify and modify risky pedestrian behaviors amongst Chinese children. Traffic Inj. Prev. 2020, 21, 108-113. [CrossRef] [PubMed]

9. Rivara, F.P.; Bergman, A.B.; Drake, C. Parental attitudes and practices toward children as pedestrians. Pediatrics 1989, 84, 1017-1021. [CrossRef] [PubMed]

10. Gielen, A.C.; DeFrancesco, S.; Bishai, D.; Mahoney, P.; Ho, S.; Guyer, B. Child pedestrians: The role of parental beliefs and practices in promoting safe walking in urban neighborhoods. J. Urban. Health 2004, 81, 545-555. [CrossRef]

11. Jiang, K.; Wang, Y.; Feng, Z.; Sze, N.N.; Yu, Z.; Cui, J. Exploring the crossing behaviours and visual attention allocation of children in primary school in an outdoor road environment. Cogn. Technol. Work 2021, 23, 587-604. [CrossRef]

12. Ištoka Otković, I.; Deluka-Tibljaš, A.; Šurdonja, S. Analysis of Children's Traffic Behaviour at Signalized Crosswalks as a Precondition for Safe Children Routes Design: A Case Study from Croatia. J. Adv. Transp. 2021, 2021, 7936261. [CrossRef]

13. Ištoka Otković, I.; Deluka-Tibljaš, A.; Šurdonja, S.; Campisi, T. Development of Models for Children-Pedestrian Crossing Speed at Signalized Crosswalks. Sustainability 2021, 13, 777. [CrossRef]

14. Deluka-Tibljaš, A.; Ištoka Otković, I.; Campisi, T.; Šurdonja, S. Comparative analyses of parameters influencing children pedestrian behavior in conflict zones of urban intersections. Safety 2021, 7, 5. [CrossRef]

15. Otković, I.I.; Deluka-Tibljaš, A.; Šurdonja, S.; Canale, A.; Tesoriere, G.; Campisi, T. Analyses of factors influencing children behaviour while crossing the conflict zones at urban intersections. In Pedestrians, Urban Spaces and Health; CRC Press: Boca Raton, FL, USA, 2020; pp. 198-203.

16. Barton, B.K.; Schwebel, D.C. The roles of age, gender, inhibitory control, and parental supervision in children's pedestrian safety. J. Pediatric Psychol. 2007, 32, 517-526. [CrossRef] [PubMed]

17. Hill, R.; Lewis, V.; Dunbar, G. Young children's concepts of danger. Br. J. Dev. Psychol. 2020, 18, 103-119. [CrossRef]

18. Tabibi, Z.; Pfeffer, K. Choosing a safe place to cross the road: The relationship between attention and identification of safe and dangerous road-crossing sites. Child: Care Health Dev. 2003, 29, 237-244. [CrossRef] [PubMed]

19. Tapiro, H.; Meir, A.; Parmet, Y.; Oron-Gilad, T. Visual search strategies of child-pedestrians in road crossing tasks. In Proceedings of the Human Factors and Ergonomics Society Europe Chapter 2013 Annual Conference: Human Factors: Sustainable Life and Mobility, Torino, Italy, 16-18 October 2013; de Waard, D., Brookhuis, K., Wiczorek, R., di Nocera, F., Brouwer, R., Barham, P., Weikert, C., Kluge, A., Gerbino, W., Toffetti, A., Eds.; 2021. Available online: http:/ /hfeseurope.org (accessed on 1 December 2021).

20. Meir, A.; Oron-Gilad, T.; Parmet, Y. Are child-pedestrians able to identify hazardous traffic situations? Measuring their abilities in a virtual reality environment. Saf. Sci. 2015, 80, 33-40. [CrossRef] 
21. Meir, A.; Parmet, Y.; Oron-Gilad, T. Towards understanding child-pedestrians' hazard perception abilities in a mixed reality dynamic environment. Transp. Res. Part F Traffic Psychol. Behav. 2013, 20, 90-107. [CrossRef]

22. Cieśla, M. Modern urban transport infrastructure solutions to improve the safety of children as pedestrians and cyclists. Infrastructures 2021, 6, 102. [CrossRef]

23. Meir, A.; Oron-Gilad, T. Understanding complex traffic road scenes: The case of child-pedestrians' hazard perception. J. Saf. Res. 2020, 72, 111-126. [CrossRef]

24. Whitebread, D.; Neilson, K. The contribution of visual search strategies to the development of pedestrian skills by $4-11$ year-old children. Br. J. Educ. Psychol. 2020, 70, 539-557. [CrossRef]

25. Tabibi, Z.; Pfeffer, K. Finding a safe place to cross the road: The effect of distractors and the role of attention in children's identification of safe and dangerous road-crossing sites. Infant Child. Dev. An. Int. J. Res. Pract. 2007, 16, 193-206. [CrossRef]

26. Tapiro, H.; Oron-Gilad, T.; Parmet, Y. The effect of environmental distractions on child pedestrian's crossing behavior. Saf. Sci. 2018, 106, 219-229. [CrossRef]

27. Oxley, J.A.; Congiu, M.; Whelan, M.; D'Elia, A.; Charlton, J. The impacts of functional performance, behaviour and traffic exposure on road-crossing judgements of young children. Annu. Proc. Assoc. Adv. Automot. Med. 2007, 51, 81-96.

28. Wang, H.; Tan, D.; Schwebel, D.C.; Shi, L.; Miao, L. Effect of age on children's pedestrian behaviour: Results from an observational study. Transp. Res. Part. F Traffic Psychol. Behav. 2018, 58, 556-565. [CrossRef]

29. Ampofo-Boateng, K.; Thomson, J.A. Children's perception of safety and danger on the road. Br. J. Psychol. 1991, 82, 487-505. [CrossRef]

30. Schwebel, D.C.; Wu, Y.; Swanson, M.; Cheng, P.; Ning, P.; Cheng, X.; Hu, G. Child pedestrian street-crossing behaviors outside a primary school: Developing observational methodologies and data from a case study in Changsha, China. J. Transp. Health 2018, 8, 283-288. [CrossRef] [PubMed]

31. Fu, L.; Zou, N. The influence of pedestrian countdown signals on children's crossing behavior at school intersections. Accid. Anal. Prev. 2016, 94, 73-79. [CrossRef]

32. Wang, H.; Schwebel, D.C.; Tan, D.; Shi, L.; Miao, L. Gender differences in children's pedestrian behaviors: Developmental effects. J. Saf. Res. 2018, 67, 127-133. [CrossRef]

33. Wang, H.; Wu, M.; Cheng, X.; Schwebel, D.C. The road user behaviours of Chinese adolescents: Data from China and a comparison with adolescents in other countries. Ann. Glob. Health 2019, 85, 76. [CrossRef]

34. Simeunović, M.; Tanackov, I.; Pitka, P.; Simeunović, M.; Papić, Z. Determination of Moving Speed of School Age Children. Math Probl. Eng. 2021, 2021, 9965753. [CrossRef]

35. Morrongiello, B.A. Caregiver supervision and child-injury risk: I. Issues in defining and measuring supervision; II. Findings and directions for future research. J. Pediatric Psychol. 2005, 30, 536-552. [CrossRef] [PubMed]

36. Schwebel, D.C.; Barton, B.K. Contributions of multiple risk factors to child injury. J. Pediatric Psychol. 2005, 30, 553-561. [CrossRef]

37. Schwebel, D.C.; Bounds, M.L. The role of parents and temperament on children's estimation of physical ability: Links to unintentional injury prevention. J. Pediatric Psychol. 2003, 28, 505-516. [CrossRef] [PubMed]

38. Rosenbloom, T.; Ben-Eliyahu, A.; Nemrodov, D. Children's crossing behavior with an accompanying adult. Saf. Sci. 2008, 46, 1248-1254. [CrossRef]

39. Schwebel, D.C.; Davis, A.L.; O’Neal, E.E. Child pedestrian injury: A review of behavioral risks and preventive strategies. Am. J. Lifestyle Med. 2012, 6, 292-302. [CrossRef]

40. Cho, G.; Rodríguez, D.A.; Khattak, A.J. The role of the built environment in explaining relationships between perceived and actual pedestrian and bicyclist safety. Accid. Anal. Prev. 2009, 41, 692-702. [CrossRef] [PubMed]

41. Agran, P.F.; Winn, D.G.; Anderson, C.L.; Tran, C.; Del Valle, C.P. The role of the physical and traffic environment in child pedestrian injuries. Pediatrics 1996, 98, 1096-1103. [CrossRef]

42. Abdel-Aty, M.; Chundi, S.S.; Lee, C. Geo-spatial and log-linear analysis of pedestrian and bicyclist crashes involving school-aged children. J. Saf. Res. 2007, 38, 571-579. [CrossRef] [PubMed]

43. Fridman, L.; Pitt, T.; Rothman, L.; Howard, A.; Hagel, B. Driver and road characteristics associated with child pedestrian injuries. Accid. Anal. Prev. 2019, 131, 248-253. [CrossRef]

44. Ivan, K.; Benedek, J.; Ciobanu, S.M. School-Aged Pedestrian-Vehicle Crash Vulnerability. Sustainability 2019, 11, 1214. [CrossRef]

45. Fu, L.; Zou, N. Analysis of Child Pedestrians' Unsafe Road Crossing Behavior at Intersections in School Zones. In Green, Smart and Connected Transportation Systems: Proceedings of the 9th International Conference on Green Intelligent Transportation Systems and Safety, Guilin, China, 1-3 July 2018; Springer Nature: Berlin/Heidelberg, Germany, 2020; Volume 617, p. 397.

46. Ferenchak, N.N.; Marshall, W.E. Redefining the child pedestrian safety paradigm: Identifying high fatality concentrations in urban areas. Inj. Prev. 2017, 23, 364-369. [CrossRef] [PubMed]

47. Chang, K.; Foss, P.; Larrea, M.; Bautista, E. Student pedestrian walking speeds at crosswalks near schools. Transp. Res. Rec. 2018 2672, 22-29. [CrossRef]

48. Wu, J.L.; Zhang, S.R.; Singh, A.K.; Wang, Q.P. Pedestrian walking speed characteristics at signalized intersections in new urban district communities. In Proceedings of the First International Conference on Transportation Infrastructure and Materials (ICTIM 2016) Xi'an, China, 16-18 July 2016; DEStech Publications, Inc.: Lancaster, PA, USA, 2016; pp. 453-461. [CrossRef]

49. Bansal, A.; Goyal, T.; Sharma, U. Modelling the Pedestrian Speed at Signalised Intersection Crosswalks for Heterogeneous Traffic Conditions. Promet-Traffic Transp. 2019, 31, 681-692. [CrossRef] 
50. Li, P.; Bian, Y.; Rong, J.; Zhao, L.; Shu, S. Pedestrian crossing behavior at unsignalized mid-block crosswalks around the primary school. Procedia-Soc. Behav. Sci. 2013, 96, 442-540. [CrossRef]

51. Bendak, S.; Alnaqbi, A.M.; Alzarooni, M.Y.; Aljanaahi, S.M.; Alsuwaidi, S.J. Factors affecting pedestrian behaviors at signalized crosswalks: An empirical study. J. Saf. Res. 2021, 76, 269-275. [CrossRef]

52. Tapiro, H.; Oron-Gilad, T.; Parmet, Y. Pedestrian distraction: The effects of road environment complexity and age on pedestrian's visual attention and crossing behavior. J. Saf. Res. 2020, 72, 101-109. [CrossRef] [PubMed]

53. Chandra, S.; Bharti, A.K. Speed distribution curves for pedestrians during walking and crossing. Procedia-Soc. Behav. Sci. 2013, 104, 660-667. [CrossRef]

54. Muley, D.; Alhajyaseen, W.; Kharbeche, M.; Al-Salem, M. Pedestrians' speed analysis at signalized crosswalks. Procedia Comput. Sci. 2018, 130, 567-574. [CrossRef]

55. Automoto. Available online: https://www.automoto.it/news/gli-smombie-i-pericolosi-pedoni-malati-di-smartphone.html (accessed on 10 December 2021).

56. Byington, K.W.; Schwebel, D.C. Effects of mobile Internet use on college student pedestrian injury risk. Accid. Anal. Prev. 2013, 51, 78-83. [CrossRef] [PubMed]

57. Ahn, I.S.; Bae, M.J.; Bae, S.G. A study on the warning sound system for smombie accident prevention using the RFID tag. J. Eng. Appl. Sci. 2019, 14, 846-850. [CrossRef]

58. Goh, H.; Kim, W.; Han, J.; Han, K.; Noh, Y. Smombie Forecaster: Alerting Smartphone Users About Potential Hazards in Their Surroundings. IEEE Access 2020, 8, 153183-153191. [CrossRef]

59. Lee, D.H.; Oh, H.S.; Jang, J.M.; Jeong, J.W.; Yang, S.O. A Study on the Current Situation and Improved Method for the Smombie through Field Survey and ICT Trend Analysis. J. Korean Soc. Saf. 2020, 35, 74-85.

60. Kim, D.; Han, K.; Sim, J.S.; Noh, Y. Smombie Guardian: We watch for potential obstacles while you are walking and conducting smartphone activities. PLOS ONE 2018, 13, e0197050. [CrossRef]

61. Dunbar, G.; Hill, R.; Lewis, V. Children's attentional skills and road behavior. J. Exp. Psychol. Appl. 2001, 7, 227. [CrossRef] [PubMed]

62. Nasar, J.; Hecht, P.; Wener, R. Mobile telephones, distracted attention, and pedestrian safety. Accid. Anal. Prev. 2008, 40, 69-75. [CrossRef]

63. Stavrinos, D.; Byington, K.W.; Schwebel, D.C. Effect of cell phone distraction on pediatric pedestrian injury risk. Pediatrics 2009, 123, e179-e185. [CrossRef]

64. Zhuang, X.; Wu, C. Pedestrians' crossing behaviors and safety at unmarked roadway in China. Accid. Anal. Prev. 2011, 43, 1927-1936. [CrossRef] [PubMed]

65. Schwebel, D.C.; Stavrinos, D.; Byington, K.W.; Davis, T.; O’Neal, E.E.; De Jong, D. Distraction and pedestrian safety: How talking on the phone, texting, and listening to music impact crossing the street. Accid. Anal. Prev. 2012, 45, 266-271. [CrossRef]

66. Ortiz, N.C.; Ramnarayan, M.; Mizenko, K. Distraction and road user behavior: An observational pilot study across intersections in Washington, DC. J. Transport. Health 2017, 7, 13-22. [CrossRef]

67. Osborne, R.; Horberry, T.; Young, K.L. Pedestrian distraction from Smartphones: An end-user perspective on current and future countermeasures. Transp. Res. Part F Traffic Psychol. Behav. 2020, 73, 348-361. [CrossRef]

68. Liu, Y.; Alsaleh, R.; Sayed, T. Modeling the influence of mobile phone use distraction on pedestrian reaction times to green signals: A multilevel mixed-effects parametric survival model. Transp. Res. Part F Traffic Psychol. Behav. 2021, 81, 115-129. [CrossRef]

69. Gruden, C.; Ištoka Otković, I.; Šraml, M. Safety Analysis of Young Pedestrian Behavior at Signalized Intersections: An EyeTracking Study. Sustainability 2021, 13, 4419. [CrossRef]

70. Gruden, C.; Ištoka Otković, I.; Šraml, M. Pedestrian safety at roundabouts: Their crossing and glance behavior in the interaction with vehicular traffic. Accid. Anal. Prev. 2021, 159, 106290. [CrossRef]

71. Droździel, P.; Tarkowski, S.; Rybicka, I.; Wrona, R. Drivers 'reaction time research in the conditions in the real traffic. Open Eng. 2020, 10, 35-47. [CrossRef]

72. Jurecki, R.S.; Stańczyk, T.L. Driver reaction time to lateral entering pedestrian in a simulated crash traffic situation. Transp. Res. Part. F Traffic Psychol. Behav. 2014, 27, 22-36. [CrossRef]

73. Mehmood, A.; Easa, S. Modeling reaction time in car-following behaviour based on human factors. Int. J. Eng. Appl. Sci. 2009, 5, 93-101.

74. Haque, M.M.; Washington, S. A parametric duration model of the reaction times of drivers distracted by mobile phone conversations. Accid. Anal. Prev. 2014, 62, 42-53. [CrossRef]

75. Choudhary, P.; Velaga, N.R. Modelling driver distraction effects due to mobile phone use on reaction time. Transp. Res. Part. C Emerg. Technol. 2017, 77, 351-365. [CrossRef]

76. Pawar, N.M.; Velaga, N.R. Modelling the influence of time pressure on reaction time of drivers. Transp. Res. Part. F Traffic Psychol. Behav. 2020, 72, 1-22. [CrossRef]

77. Zeng, W.; Chen, P.; Nakamura, H.; Iryo-Asano, M. Application of Social Force Model to Pedestrian Behavior Analysis at Signalized Crosswalk. Transp. Res. Part Emerg. Technol. 2014, 40, 143-159. [CrossRef]

78. Gruden, C.; Ištoka Otković, I.; Šraml, M. Neural Networks Applied to Microsimulation: A Prediction Model for Pedestrian Crossing Time. Sustainability 2020, 12, 5355. [CrossRef] 
79. Gitelman, V.; Levi, S.; Carmel, R.; Korchatov, A.; Hakkert, S. Exploring patterns of child pedestrian behaviors at urban intersections. Accid. Anal. Prev. 2019, 122, 36-47. [CrossRef]

80. Schwab, B.; Beil, C.; Kolbe, T.H. Spatio-Semantic Road Space Modeling for Vehicle-Pedestrian Simulation to Test Automated Driving Systems. Sustainability 2020, 12, 3799. [CrossRef]

81. Pinna, F.; Murrau, R. Age Factor and Pedestrian Speed on Sidewalks. Sustainability 2018, 10, 4084. [CrossRef]

82. Pinna, F.; Murrau, R. Isolated and Single Pedestrians and Pedestrian Groups on Sidewalks. Infrastructures 2017, 2, 21. [CrossRef]

83. Chang, C.Y.; Woo, T.H.; Wang, S.F. Analysis of Pedestrian Walking Speeds at Crosswalks in Taiwan. J. East. Asia Soc. Transp. Stud. 2011, 9, 1186-1200. [CrossRef]

84. Iryo-Asano, M.; Alhajyaseen, W.K.M. Modeling pedestrian crossing speed profiles considering speed change behavior for the safety assessment of signalized intersections. Accid Anal. Prev. 2017, 108, 332-342. [CrossRef] [PubMed]

85. Russo, B.J.; James, E.; Aguilar, C.Y.; Smaglik, E.J. Pedestrian Behavior at Signalized Intersection Crosswalks: Observational Study of Factors Associated with Distracted Walking, Pedestrian Violations, and Walking Speed. Transp. Res. Rec. 2018, $2672,1-12$. [CrossRef]

86. Zafri, N.M.; Rony, A.I.; Adri, N. Analysis of Pedestrian Crossing Speed and Waiting Time at Intersections in Dhaka. Infrastructures 2019, 4, 39. [CrossRef]

87. Ištoka Otković, I. A Model to Predict Children's Reaction Time at Signalized Intersections. Safety 2020, 6, 22. [CrossRef] 